For submission to Journal of Proteome Research

\title{
Comparisons of Protein and Peptide Complexity in Poneroid and Formicoid Ant Venoms
}

Samira R. Aili ${ }^{\dagger}$, Axel Touchard ${ }^{\ddagger}$, Jennifer M. S. Koh ${ }^{\dagger}$, Alain Dejean ${ }^{\ddagger, \S}$, Jérôme Orivel ${ }^{\ddagger}$, Matthew P. Padula", Pierre Escoubas", Graham M. Nicholson ${ }^{\dagger, *}$

${ }^{\dagger}$ Neurotoxin Research Group, School of Life Sciences, Faculty of Science, University of Technology Sydney, NSW 2007, Australia

${ }^{\ddagger}$ CNRS, UMR Ecologie des Forêts de Guyane (EcoFoG), Campus Agronomique, BP 316, 97379 Kourou Cedex, France

¿Laboratoire Écologie Fonctionnelle et Environnement, CNRS, UMR 5245, Ecolab, 118 route de Narbonne, 31062 Toulouse, France

IProteomics Core Facility, Faculty of Science, University of Technology Sydney, NSW 2007, Australia

\#VenomeTech, 473 Route des Dolines - Villa 3, Valbonne 06560, France

\section{AUTHOR INFORMATION}

\section{Corresponding Author}

* Prof. Graham M. Nicholson, Neurotoxin Research Group, School of Life Sciences, Faculty of Science, University of Technology Sydney, NSW 2067, Australia. Phone: (+61) 95142230. Fax: (+61) 9514 1656. E-mail: Graham.Nicholson@uts.edu.au

\section{Author Contributions}

The manuscript was written through contributions of all authors.

\section{Notes}

The authors declare no competing financial interest. 
ABSTRACT: Animal venom peptides are currently being developed as novel drugs and bioinsecticides. Since ants use venoms for defence and predation, venomous ants represent an untapped source of potential bioactive toxins. This study compared the protein and peptide components of the poneroid ants Neoponera commutata, Neoponera apicalis, and Odontomachus hastatus, and the formicoid ants Ectatomma tuberculatum, Ectatomma brunneum and Myrmecia gulosa. 1D and 2D PAGE revealed venom proteins in the mass range $<10 \mathrm{kDa}$ to $>250 \mathrm{kDa}$. NanoLC-ESI-QTOF MS/MS analysis of tryptic peptides revealed the presence of common venom proteins but also many undescribed proteins. RP-HPLC separation followed by MALDI-TOF MS of the venom peptides also revealed considerable heterogeneity. It was found that the venoms contained between 144-1032 peptides with 5$95 \%$ of peptides in the ranges $1-4 \mathrm{kDa}$ and $1-8 \mathrm{kDa}$ for poneroid and formicoid ants, respectively. By employing the reducing MALDI matrix 1,5-diaminonapthalene, up to 28 disulfide-bonded peptides were also identified in each of the venoms. In particular, the mass range of peptides from poneroid ants is lower than peptides from other venoms, indicating possible novel structures and pharmacologies. These results indicate that ant venoms represent an enormous, untapped source of novel therapeutic and bioinsecticide leads.

KEYWORDS: Hymenoptera, toxin, proteomic analysis, mass spectrometry, peptidome, ant venom, LC-MALDI-TOF MS, nanoLC-ESI-QTOF MS/MS

\section{INTRODUCTION}

Arthropod venoms contain a vast number of insecticidal peptide toxins that are yet to be characterised. The current estimate for the numbers of uncharacterised bioactive peptides within spider venoms alone is in the millions ${ }^{1}$, from a predicted total of 170,000 species $^{2}$. Ant 
venoms are even less characterised; out of a total of 9000 stinging species, only 11 species have been investigated ${ }^{3,4}$.

Ants and other stinging insects, such as Apoidea (bees) and Vespoidea (wasps), belong to the family Formicidae of the order Hymenoptera ${ }^{5}$. Ants represent a diverse group of arthropods $^{6}$, with approximately 13,000 extant species ${ }^{7}$ and an estimated total of 25,000 described and undescribed species $^{8,9}$. Ants are considered leading invertebrate predators, with some adapted to prey upon certain groups of insects using their venom ${ }^{10}$. However, their venom is also used for other purposes including defence against predators and social communication $^{11}$. The success of ants is reflected by their representation of $15-20 \%$ of the rainforest animal biomass ${ }^{12}$.

The limited work done thus far reveals that ant venoms show enormous chemical diversity comprising alkaloids, hydrocarbons, proteins and peptides ${ }^{3,4}$. Most studies on ant venoms have focused on the alkaloidal components, as these are a major cause of allergic reactions due to their histamine-releasing properties ${ }^{13}$, 14 . However, more recent studies have shown the involvement of the proteome in eliciting these allergic ${ }^{15,} 16$ and antiinflammatory ${ }^{17,18}$ properties. Additional studies have also revealed that the peptidome is a source of antimicrobial activity against both Gram-positive and Gram-negative bacteria ${ }^{6,11}$. Neurotoxic ant venom peptides have also been identified and appear to be important for defence and prey capture ${ }^{19}$. This is an extremely understudied area of research, as only two neurotoxic ant peptides have been extensively characterised; poneratoxin ${ }^{20,} 21$ and ectatomin ${ }^{22}$.

The limited number of studies on ant peptides reveal that they either linear (e.g. pilosulin), homo- or heterodimeric (e.g. ectatomins), or contain an inhibitor cystine knot structural motif 3,23 . The number studies on ant venoms have been restricted by the small 
amount of venom secreted by ants, which makes it difficult to extract sufficient material for proper purification and characterisation ${ }^{24}$. However, the previous lack of high sensitivity analytical tools ${ }^{6}$ has recently been overcome by improvements in mass spectrometric instrumentation ${ }^{25,26}$.

While the number of biologically active peptides from all described venomous animal species is estimated to approach 20 million, to-date only 75 peptides are described from ant venoms $^{3,4,25}$. Consequently, ants are an understudied source of neurotoxic peptides that could be used as leads for novel bioinsecticidal compounds. Strong indicators include the use of their venom for predation and defence against other insects ${ }^{27}$, and the presence of disulfide-rich, low molecular weight peptides $^{3,4}$. These types of peptides are readily absorbed, highly stable and resistant to degradative environmental factors ${ }^{28,29}$. Given the limited investigation of ant venoms this study aimed to investigate the complexity of the protein and peptide components of six different ant venoms from the two major ant clades: formicoids and poneroids. The present study found that ant venoms are, indeed, rich in both peptides and proteins that could serve as potential sources of structurally and pharmacologically novel neurotoxins. These could be mined for potential biopesticides to control agricultural pests and insect vectors that transmit diseases.

\section{EXPERIMENTAL SECTION}

\section{Ant Collection and Taxonomy}

Live specimens of worker ants from the poneroid species Neoponera commutata, Neoponera apicalis and Odontomachus hastatus (Ponerinae) and the formicoid species Ectatomma tuberculatum and Ectatomma brunneum (Ectatomminae) were collected from several regions of French Guiana. Collected ants were stored at $-20^{\circ} \mathrm{C}$ prior to dissection of 
the venom glands. Dissected glands from an individual species were pooled in $10 \%$ acetonitrile $(A C N)$ in water $(v / v)$. Samples were centrifuged for 5 min at $14,400 \mathrm{rpm}(12,000$ $\left.g_{\text {av }}\right)$. The supernatant was then collected and lyophilised prior to storage at $-20^{\circ} \mathrm{C}$. Lyophilised Myrmecia gulosa (formicoid clade; Myrmeciinae) venom was purchased from Southwestern Biological Institute (Flagstaff, AZ, USA). All chemicals used were of analytical grade and sourced from Sigma-Aldrich Pty Ltd (Castle Hill, NSW, Australia). All buffers were prepared using milli-Q water.

\section{Protein Assay}

Protein quantification was performed using a QuantiPro BCA Assay Kit (Sigma-Aldrich) or Qubit Protein Assay Kit (Invitrogen, Mulgrave, Victoria, Australia) with the Qubit 2.0 fluorometer as per the manufacturer's instructions using bovine serum albumin (BSA) as the standard.

\section{One-dimensional gel electrophoresis}

$100 \mu \mathrm{g}$ of crude venom samples were mixed with $12 \mu \mathrm{l}$ SDS sample buffer (15 mM Tris, $\mathrm{pH}$ $6.8 ; 0.25 \%(\mathrm{w} / \mathrm{v})$ SDS; $0.25 \%(\mathrm{v} / \mathrm{v}) \beta$-mercaptoethanol; $2.5 \%(\mathrm{v} / \mathrm{v})$ glycerol and $0.0025 \%(\mathrm{w} / \mathrm{v})$ bromophenol blue) and boiled as previously described ${ }^{30}$. Samples were then centrifuged at $16,873 g_{\text {av }}$ for 5 min before being loaded into a 4-20\% Criterion TGX gel (Bio-Rad, Gladesville, NSW, Australia) and electrophoresed in Tris-glycine-SDS running buffer (Bio-Rad) alongside Precision Plus Protein ${ }^{\mathrm{TM}}$ standards (Bio-Rad). The gel was run for approximately $30 \mathrm{~min}$ at $300 \mathrm{~V}$, until the dye front reached the bottom of the gel. The gel was then placed in a fixing solution containing $40 \%(\mathrm{v} / \mathrm{v})$ methanol and $10 \%(\mathrm{v} / \mathrm{v})$ acetic acid for $30 \mathrm{~min}$ at room temperature before staining with Flamingo fluorescent stain (Bio-Rad) for one hour. After staining, the gel was scanned using a Molecular Imager PharosFX Plus system (Bio-Rad) with QuantityOne $^{\circledR}$ software. In order to perform nanoLC-ESI-QTOF MS/MS, gels were 
additionally stained with Coomassie Blue G250 overnight then destained with $1 \%(\mathrm{v} / \mathrm{v})$ acetic acid for $2 \mathrm{~h}$.

\section{Two-dimensional gel electrophoresis}

$300 \mu \mathrm{g}$ samples of $N$. commutata and E. tuberculatum venom were re-suspended in $100 \mu \mathrm{l} 7$ $\mathrm{M}$ urea, $2 \mathrm{M}$ thiourea, $1 \%(\mathrm{v} / \mathrm{v}) \mathrm{C} 7 \mathrm{BzO}, 50 \mathrm{mM}$ Tris $\mathrm{HCl} \mathrm{pH} 8.8$ before reduction and alkylation of disulphide bonds with $5 \mathrm{mM}$ tributylphosphine and $20 \mathrm{mM}$ acrylamide monomers for 90 min. The venom was then desalted using a BioSpin column (Bio-Rad) equilibrated in $7 \mathrm{M}$ urea, $2 \mathrm{M}$ thiourea, $1 \%(\mathrm{v} / \mathrm{v}) \mathrm{C7BzO}$. The sample was subjected to 2D-PAGE as previously described ${ }^{31}$. Briefly, sample was fractionated by isoelectric focusing on an $11 \mathrm{~cm} \mathrm{pH3-10} \mathrm{IPG}$ strip (Bio-Rad) for $100 \mathrm{kVh}$ and then separated on a second dimension on a $4-20 \%$ gel. The gels were subsequently visualised by staining with Flamingo Gel Stain or Coomassie Blue G250 as per section 2.3.1.

\section{Protein Identification}

Gel spots or bands were excised, digested as previously described ${ }^{32}$ and subjected to nanoLC-ESI-QTOF MS/MS. In brief, tryptic digests of proteins in gel spots or bands were placed on a Tempo nanoLC system (Eksigent, Waverley, Victoria, Australia) and loaded onto a Michrom reversed-phase trapping cartridge at a rate of $20 \mu \mathrm{l} / \mathrm{min}$ with MS loading solvent, consisting of $2 \%$ acetonitrile ( $\mathrm{ACN}$ ) and $0.2 \%$ trifluoroacetic acid (TFA), onto a $\mathrm{C} 8$ trap column (Michrom Biosciences, USA). The samples were eluted at 300nl/min onto a $75 \mu \mathrm{m} \times 150 \mathrm{~mm}$ PicoFrit column (New Objective, USA) packed with Magic C18AQ chromatography resin (Bruker-Michrom Biosciences, Auburn, CA, USA). Peptides were eluted from the column and into the source of a QSTAR Elite hybrid quadrupole-time-of-flight mass spectrometer (AB SCIEX, Framingham, MA, USA) using the following program: $5-50 \%$ MS solvent $B(98 \% A C N+$ $0.2 \%$ formic acid) over 8 minutes, $50-80 \%$ MS buffer B over 5 minutes, $80 \%$ MS buffer B for 
2 minutes, $80-5 \%$ for 3 min. MS solvent $A$ was $2 \% A C N+0.2 \%$ formic acid. The eluting peptides were ionised with a $75 \mu \mathrm{m}$ ID emitter tip that tapered to $15 \mu \mathrm{m}$ (New Objective) at 2300V. An Intelligent Data Acquisition (IDA) experiment was performed, with a mass range of 375-1500 Da continuously scanned for peptides of charge state $2^{+}-5^{+}$with an intensity of more than 30 counts/s. Selected peptides were fragmented and the product ion fragment masses measured over a mass range of 100-1500 Da. The mass of the precursor peptide was then excluded for $15 \mathrm{~s}$.

The MS/MS data files produced by the QSTAR were searched using Mascot Daemon (version 2.4, provided by the Walter and Elisa Hall Institute ${ }^{33}$ ) and searched against the LudwigNR database (comprised of the UniProtKB, plasmoDB and Ensembl databases vQ215; $19,375,804$ sequences with $6,797,271,065$ residues) with the following parameter settings. Fixed modifications: none. Variable modifications: propionamide $\mathrm{C}$, oxidised $\mathrm{M}$, deamidation NQ. Enzyme: semi-trypsin. Number of allowed missed cleavages: 3. Peptide mass tolerance: $100 \mathrm{ppm} . \mathrm{MS} / \mathrm{MS}$ mass tolerance: $0.2 \mathrm{Da}$. Charge state: $2^{+}, 3^{+}$and $4^{+} . \mathrm{MS} / \mathrm{MS}$ data files were also searched against Hymenopteran proteins in the NCBInr protein database using PEAKS 6 software (Bioinformatics Solutions Inc., Waterloo, ON, Canada). The results from both searches were then filtered by including only protein hits with at least one unique peptide. Peptides identified by PEAKS 6 were further validated by manual inspection of the MS/MS spectra for the peptide to ensure the $b$ - and $y$-ion series were sufficiently extensive for an accurate identification.

\section{C18 Crude Venom RP-HPLC Fractionation}

Lyophilized crude venom was separated using a Vydac analytical C18 RP-HPLC column (218TP54, $25 \mathrm{~cm} \times 4.6 \mathrm{~mm}, 5 \mu \mathrm{m}$ pore size) on a Shimadzu HPLC system. Fractionation of 
venom peptide components was achieved using a linear gradient of two mobile phases: $0.1 \%$ $(\mathrm{v} / \mathrm{v})$ trifluoroacetic acid (TFA) in water (solvent A) and $0.085 \%(\mathrm{v} / \mathrm{v})$ TFA in ACN (solvent B). For all venoms except $E$. brunneum, separation was achieved using a flow rate of $1 \mathrm{ml} / \mathrm{min}$ with the following gradient of: $0-5 \mathrm{~min}, 0 \%$ solvent $\mathrm{B} ; 5-65 \mathrm{~min}, 0-60 \% \mathrm{~B} ; 65-75 \mathrm{~min}, 60-$ $90 \% \mathrm{~B} ; 75-80 \mathrm{~min}, 90 \% \mathrm{~B} ; 80-85 \mathrm{~min}, 90-0 \% \mathrm{~B}$; and $85-90 \mathrm{~min}, 0 \% \mathrm{~B}$. For E. brunneum venom separation used a slightly longer gradient to facilitate isolation of the more hydrophobic peptides comprising: $0-10 \mathrm{~min}, 5 \%$ solvent B; $10-80 \mathrm{~min}, 5-70 \% \mathrm{~B} ; 80-90 \mathrm{~min}$, 70-95\% B; 90-95 min, 95\% B; 95-100 min, 95-5\% B; and 100-105 min, 5\% B. Peaks were monitored at absorbances of $280 \mathrm{~nm}$ and $215 \mathrm{~nm}$ and manually collected, then lyophilised and stored at $-20^{\circ} \mathrm{C}$ for further use.

\section{MALDI-TOF MS Analysis}

MS analysis of the HPLC fractions was performed on a AB SCIEX 5800 MALDI-TOF/TOF mass spectrometer. Initial experiments were performed using several MALDI matrices on $E$. tuberculatum HPLC fractions to test for optimum peptide ionisation and crystallisation. The four matrices tested were: $5 \mathrm{mg} / \mathrm{ml}$ of $\alpha$-cyano-4-hydroxycinnamic acid (CHCA) dissolved in $1 \%(v / v)$ TFA/100\% (v/v) ACN/0.1 $\mathrm{M} \mathrm{NH}_{4} \mathrm{H}_{2} \mathrm{PO}_{4}$ (45/45/10); $10 \mathrm{mg} / \mathrm{ml}$ ferulic acid (FA) in 40\% (v/v) ACN/10 mM serine; $10 \mathrm{mg} / \mathrm{ml} \mathrm{N}$-tert-butyl-N-isopropyl-N-methylammonium $\alpha$-cyano-4hydroxycinnamate (ionic CHCA) in 0.1\% (v/v) formic acid/50\% (v/v) ACN; and a 1:1 mixture of CHCA and FA. All venom fractions were reconstituted with $10 \mu$ water. Then, $1 \mu$ of each fraction was overlaid with $0.5-0.75 \mu$ l of the matrix using the dried droplet method ${ }^{34}$. Each spectrum was calibrated externally using a mixture of peptides with known molecular masses in the same $m / z$ range (AB SCIEX). Mass spectra were acquired in linear mode over the range $1,000-10,000 \mathrm{~m} / \mathrm{z}$ with 400 laser shots accumulated for each sample, based on the acceptance parameters and adequate signal intensity. Mass spectra were collected in 
positive ion mode and signals below $1,000 \mathrm{~m} / \mathrm{z}$ were not recorded as they were comprised of mostly matrix-related ion clusters ${ }^{35}$.

\section{Identification of Disulfide-Bonded Peptides}

Disulfide-bonded peptides were identified by chemical reduction of HPLC fractions. RP-HPLC fractions were spotted onto a MALDI plate as detailed in Section 2.4.1 and overlaid with the reducing matrix 1,5-diaminonapthalene $(1,5-\mathrm{DAN} ; 10 \mathrm{mg} / \mathrm{ml})$ in $0.05 \%(\mathrm{v} / \mathrm{v})$ formic acid $/ 50 \%$ $(\mathrm{v} / \mathrm{v}) \mathrm{ACN}^{36}$. The matrix was always prepared immediately before use due to the instability of 1,5-DAN in ACN. All MALDI-TOF data collected using 1,5-DAN or CHCA matrix were acquired in reflector mode to isotopically resolve ions for comparison purposes. Chemical reduction results in a mass increase of $2 \mathrm{Da}$ for each disulfide bond. Thus, by comparing the mass spectra of native and reduced samples the number of disulfide bonds in ant venom peptides could be determined.

\section{Data analysis}

Data Explorer $^{\circledR}$ v4.11 software (AB SCIEX) was used to analyse spectra from individual RPHPLC fractions to characterise the number and masses of peptides per venom, as previously reported ${ }^{37}$. Briefly, spectra were subjected to baseline correction with a correlation factor of 0.7 and Gaussian smoothing to reduce noise with a 5-point filter width. All mass attributions were verified manually and a mass list created for each LC-MALDI-TOF MS run. Potential adducts from oxidation, hydration, sodium, and deamination were manually removed from all mass lists, as well as any potential dimers or doubly-charged species. Peptides with mass matches within $\pm 1.0 \mathrm{Da}$ in adjoining HPLC fractions were considered identical and were removed from the data set as they likely reflect incomplete separation. For each venom, the peptides from each RP-HPLC fraction were consolidated into one mass list. Mass matching across data sets was performed in Microsoft Excel (Redmond, USA) to identify similar 
peptides across the different venoms or between different data sets of the same venom when comparing matrices. Two-dimensional scatter plots, termed "2D venom landscapes", were constructed using Prism v6 software (GraphPad, La Jolla, CA USA). All peptide masses detected in each HPLC fraction were plotted as a function of their $m / z$ values ( $x$-axis) and their HPLC retention time reflecting their hydrophobicity ( $y$-axis).

\section{RESULTS}

\section{Venom Protein Characterisation}

Initially, a 1D-PAGE of all venoms was performed to determine overall venom protein profiles. It was found that the six ant venoms all had unique protein compositions (Fig. 1A). N. commutata venom contained the highest number of proteins in the range $10-250 \mathrm{kDa}$, while $E$. tuberculatum venom also had a high number of proteins mainly in the range 10-80 $\mathrm{kDa}$. The remaining venoms all had diverse and often complex protein profiles apart from $O$. hastatus, with only three distinct protein bands. Despite this clear heterogeneity in protein composition, the 1D-PAGE electrophoretic protein profiles revealed similarities among all six venoms (red boxes in Fig. 1A). For example, using nanoLC-ESI-QTOF MS/MS the ca. $90 \mathrm{kDa}$ band seen in all venoms was identified as dipeptidyl peptidase IV in all cases except $O$. hastatus. Another common feature of most venoms was the presence of bands below ca. 13 $\mathrm{kDa}$.

To identify these proteins, 2D-PAGE was performed on the venoms of $N$. commutata and E. tuberculatum. The remaining venoms were not investigated due to the limited amount of material. The 2D-PAGE spot patterns obtained after flamingo staining are depicted in Fig. 1B-C. The 2D gel of $N$. commutata venom had a large cluster of low molecular mass proteins (spots 2-5, 17-19; corresponding to ca. $10-15 \mathrm{kDa}$ ) present in the 
lower right corner of the 2D gel at ca. $\mathrm{pH} 10$. This was not seen with E. tuberculatum venom that had a greater number of higher molecular weight proteins, particularly ca. 90 kDa (Fig. 1C). Nevertheless, there were several similarities between the two gels, such as very few acidic proteins. Both gels also had several spots with isoforms, such as those at $15 \mathrm{kDa}$ in both venoms (e.g. N. commutata spots 9-11, E. tuberculatum spots 1-5), ca. 40 kDa for N. commutata (spots $13-16,24$ ) and ca. $80 \mathrm{kDa}$ for E. tuberculatum at neutral pH.

Due to the limited number of sequenced ant genomes, the generated nanoLC-ESI-QTOF MS/MS data were initially searched with Mascot, however no significant hits were seen. Therefore all data, including peptides that were identified by de novo sequencing in PEAKS 6, were searched against the NCIBnr database using PEAKS 6. The results of this search are summarised in Tables 1 and 2. From all the spots subjected to MS/MS analysis, 14 of the 26 N. commutata and 14 of the $25 \mathrm{E}$. tuberculatum 2D gel spots analysed matched to proteins. None of these were proteins from the ants investigated, due to no entries being present for those species in databases. The remaining spots could not be matched to any known ant or other hymenopteran proteins, despite the numerous high quality MS/MS spectra and de novo peptide sequences generated, including 136 spectra from spot 8 of the $N$. commutata gel. Several of the spots were matched to proteins using a single peptide, the MS/MS spectra for these spots have been included in the supporting information file as supplementary Figures S2-S16).

Of all the matches, three proteins were common to both gels. Firstly, phospholipase $A_{2}$ $\left(P L A_{2}\right)$ proteins were identified, although in completely different positions in the gels from the two different species. The E. tuberculatum PLA 2 was identified at ca. $\mathrm{pl} 7$ and mass of ca. 15 kDa (Fig. 1C; spot 2). However, the N. commutata PLA 2 was identified at a pl of 10 and mass of ca. 26 kDa (Fig. 1B; spot 20), potentially as a result of dimerisation. The second 
protein common to both species was venom acid phosphatase, in $N$. commutata it was found in both spots 2 and 10 and in E. tuberculatum it was found in spots 13-15. The third protein common to both venoms was identified as dipeptidyl peptidase. Although this protein was not identified in the 2D gel of $N$. commutata, it was detected from the $1 \mathrm{D}$ gel slice (Fig. 1A). The mass of this protein was ca. $90 \mathrm{kDa}$ in the $1 \mathrm{D}$ gels from both $E$. tuberculatum and $N$. commutata venom (Fig. $1 \mathrm{~A}$ ) as well as in the $2 \mathrm{D}$ gel of E. tuberculatum venom (Spot $18-23$, Fig. 1C).

In both venoms, the mass of some spots on the gel did not correspond to the exact theoretical mass of their assigned protein. For example, N. commutata spot 10 is at ca. 15 $\mathrm{kDa}$ and $\mathrm{pl}$ of 6 , which is ca. $3 \mathrm{kDa}$ lighter than the predicted protein, although a similar pl. One spot that seems to be far from the predicted position of the protein is $E$. tuberculatum spot 1 , as seen in Fig. 1C. It is at approximately $15 \mathrm{kDa}$ on the gel and at approximately pH 8. This is significantly different to the assigned protein's calculated mass of $91 \mathrm{kDa}$ and $\mathrm{pl}$ of 8 , as indicated in Table 2. This is most likely the result of post-translational modification, where the produced protein has undergone proteolysis, either for activation of function or degradation.

\section{Ant Venom Peptide Characterisation}

Whole Venom C18 RP-HPLC Separation. The venom of each ant was separated using RP-HPLC in order to reveal the complexity of the venoms while avoiding possible ion suppression effects known to occur in electrospray when using complex mixtures of peptides such as venoms. This initial separation step revealed complex chromatographic profiles (Fig. 2) with each venom yielding a number of venom fractions. All the venoms, except that of $E$. 
brunneum, appeared to contain quite hydrophilic peptides, as most of the peptides eluted early in the chromatogram at acetonitrile concentrations $<30 \%$.

MALDI-TOF MS Matrix optimisation. Our recent work has shown that DHB, sinapinic acid, caffeic acid and 2,4,6-trihydroxyacetophenone (THAP) are poor MALDI matrices for the automated detection of ant venom peptides and that FA and CHCA allow for the detection of the greatest number of peptides with the highest intensities ${ }^{38}$. Accordingly, initial experiments tested four different combinations of these two matrices to determine the best one to use for the remainder of the study: CHCA alone, ionic CHCA, FA alone, and FA in combination with CHCA. Of these matrices, the matrix that covered the largest mass range was FA (Fig. 3A). However, the matrix yielding the highest peptide count was CHCA (Fig. 3B), therefore, all remaining venoms investigated were analysed with both CHCA and FA.

Number of Ant Venom Peptides and Mass distribution. Each HPLC fraction from the six venoms was spotted onto a MALDI target with either CHCA or FA matrix to determine the number of peptides per fraction and their mass distribution. Although the ant venom RPHPLC fractions were seemingly homogenous, with sharp peaks, several peptides were often observed in the same fraction when further resolved by MALDI-TOF MS. There were clear differences in the abundance of masses from each chromatographic peak, as well as differences in the mass range of peptides detected and intensities between the two matrices. A single RP-HPLC fraction mostly contained multiple signal peaks that corresponded to different masses. For example, 37 masses were observed in $f 10$ from $N$. commutata venom using FA and 26 masses using CHCA (Fig. 4A). Furthermore, many low UV absorbance peaks from the RP-HPLC displayed significant numbers of peptides (e.g. 35 peptides in N. commutata f4; Fig. 4Bb). Conversely, fractions with high UV absorbances 
sometimes only had low numbers of peptides in their MALDI spectrum using either CHCA or FA. For example, $N$. commutata $f 21$ contained only a single high intensity mass at 3364.9 $m / z$ (Fig. 4C). Overall, FA appeared to be better at detecting peptides in the poneroid venoms, and was more efficient at detecting lower molecular weight peptides below 1800 Da in the formicoid venoms. However, CHCA was better at detecting peptides in formicoid venoms above $1800 \mathrm{Da}$ (Fig. 3C and shaded area of Fig. 8Ab).

Frequency histograms in 100 Da bins were constructed to show the full peptide mass distribution of all masses detected. The data showed that, in general, ponerine ant venoms have peptides with similar masses, with most of the peptides below $4 \mathrm{kDa}$ (Fig. 5). In contrast, the formicoid venoms appear to have a broader peptide mass range with a significant number of peptides in the range 4-9 kDa (Fig. 6). Peptide peak assignment resulted in between 54 (E. brunneum venom using FA matrix) and 1032 ( $N$. commutata venom using FA matrix) distinguishable peptide masses for the six ant venoms. The two matrices gave similar numbers of peptides, with $N$. commutata being the only venom to have markedly different peptide counts using the two matrices.

Despite the relatively high peptide counts, there exists the possibility that the two matrices were detecting different peptides. Using the separate mass lists created using CHCA and FA matrices, masses common to both data sets $( \pm 1 \mathrm{Da})$ were identified using an in-house mass-matching Microsoft Excel spread sheet. This analysis revealed a large number of peptides that were only detected using one of the two matrices. For example, with $N$. commutata venom only 245 peptides were detected using both FA and CHCA from a total of 1032 peptides detected using FA alone (24\%) and 574 peptides using CHCA alone (43\%). This leaves 787 unique peptides detected by FA alone and 329 unique peptides detected by CHCA 
alone. Together, the total mass count for N. commutata was therefore 1361 peptides $(245+787+329)$. The data for all six venoms is presented in the form of area-proportional Euler plots in Fig. 7.

Inter-Species Variations in Peptide Masses. If ant venoms are to be exploited as chemical libraries of unique peptides, it is important to determine if there is sufficient peptide heterogeneity between various ant venoms both across, and within, ant subfamilies. Firstly, LC-MALDI-TOF mass spectrometry revealed that all ant venoms investigated in the present study showed differences in the broad distribution of masses within the range 1-10 kDa, with limited overlap (see Fig. 5-7). Using the same mass lists generated from LCMALDI-TOF MS, an analysis of masses common to different venoms was undertaken. Comparisons were made between ants belonging to the poneroid clade and those belonging to the formicoid clade. Analyses were carried out using both CHCA and FA as MALDI matrices to negate any bias in peptide identification.

Area-proportional Euler plots (Fig. 8) revealed only limited overlap of masses between ants from the same clades, as only 16 peptides were common to all three poneroid ants and only 2 peptides common between the three formicoid ants using CHCA matrix. These numbers were similar to those obtained using FA. In general, the poneroid ants appeared to have more peptides in common, compared to formicoid ants, with $O$. hastatus and $N$. commutata sharing the highest number of peptides.

Disulfide Bond Identification. Peptides with disulfide bonds are highly stable and inherently more resistant to proteases ${ }^{29}$. In order to identify disulfide-bonded peptides present in each ant venom, individual LC fractions were spotted on a MALDI target plate along with the reducing matrix 1,5-DAN and subjected to MALDI-TOF MS in reflector mode. 
Fractions were also analysed using the non-reducing matrix CHCA in reflector mode for comparison purposes. Each peptide peak obtained with the 1,5-DAN matrix was then analysed for $\mathrm{a}+2 \mathrm{Da}$, or greater, shift from the native mass obtained using CHCA matrix (see Supplementary Figure S1).

The six venoms were found to contain variable numbers of disulfide-bonded peptides. This ranged from 2 disulfide-bonded peptides in $M$. gulosa venom to 28 disulfide-bonded peptides in E. tuberculatum venom (Fig. 9A-F). These peptides were usually of low mass (typically $<3 \mathrm{kDa}$ ) and distributed across the full HPLC chromatogram. The one exception was $E$. tuberculatum venom where disulfide-bonded peptides were detected in two distinct groups in the ranges $1-2 \mathrm{kDa}$ and 3-4 kDa (Fig. 9G). As a percentage of the total number of peptides, $N$. apicalis had the greatest proportion of disulfide-bonded peptides $(10.2 \%)$, followed by O. hastatus (9.0\%), E. tuberculatum (7.6\%), E. brunneum (5.0\%), N. commutata (3.7\%) and M. gulosa (1.4\%). What can also be seen in the $2 \mathrm{D}$ landscapes in Fig. $9 \mathrm{~A}-\mathrm{F}$ is that multiple peptides co-elute in each LC fraction, with some fractions containing more than 50 peptides. It can also be seen that peptide mass distribution is independent of the RP-HPLC retention time (hydrophobicity).

\section{DISCUSSION}

Until recently, knowledge of the composition and properties of ant venoms was limited despite the fact that ants are amongst the most widespread of all social insects ${ }^{39}$. The present study constitutes the first characterisation and comparison of the proteome and peptidome of ants belonging to the poneroid and formicoid clades. 


\section{Ant Venom Proteomes}

The 1D- and 2D-PAGE gels confirmed the complexity of ant venom proteomes as well as the broad inter-species variation in protein expression. The 2D-PAGE separation of both $N$. commutata and E. tuberculatum resulted in over 70 spots being resolved, significantly higher than the 25 spots previously described from S. invicta venom, one of the only ant venoms on which a 2D-PAGE has been performed ${ }^{16,24}$. Not surprisingly, there were some proteins that were shared between $N$. commutata and E. tuberculatum venoms after examination by 2DPAGE. The 90-kDa protein band present in all six venoms from the 1D-PAGE and confirmed in E. tuberculatum by 2D-PAGE, was identified as dipeptidyl peptidase IV. There was also a band common to all six venoms at ca. $24 \mathrm{kDa}$ in the $1 \mathrm{D}-\mathrm{PAGE}$ gels, identified as a PLA ${ }^{17,40}$. This was confirmed by the nanoLC-ESI-QTOF MS/MS identification of PLA 2 in both 2D-PAGE gels around this molecular weight range. This is a common allergenic protein of ant venoms ${ }^{17}$ and other hymenopterans $s^{41}$, although the $\mathrm{PLA}_{2}$ from the fire ant Solenopsis invicta is not considered as an allergenic protein ${ }^{42}$.

Overall, the majority of spots were assigned to proteins from hymenopteran species, where there is a high conservation of protein sequences, especially between bees, wasps and ants ${ }^{43}$, 44. For example, the known insect venom allergen lysosomal acid phosphatase, also found in honeybees was identified in both ant venoms $s^{45-47}$. An interesting protein that was identified in the $N$. commutata gel was the antimicrobial, insecticidal and haemolytic peptide ponericin. This peptide was first isolated from the venom of the closely related ant N. goeldii, from the same genus ${ }^{11}$, and has been found in other ants ${ }^{15}$. This protein was identified in several spots throughout the gel which suggests the presence of a precursor protein which is cleaved into ponericin. 
A small number of the spots were identified as contaminants or artifacts of the venom extraction procedure, as the identified proteins are not believed to represent venom peptide toxins. For example, actin present in the $N$. commutata venom is most likely a contaminant of the exoskeleton ${ }^{48}$ or reservoir gland ${ }^{49}$ while endochitinase present in E. tuberculatum venom hydrolyses chitin, an important protein for insect growth and morphogenesis ${ }^{50}$. The enzyme trehalase identified in $N$. commutata venom is also believed to be another contaminant, as it is a haemolymph protein involved in the rapid supply of energy for insects by converting trehalose to glucose ${ }^{51}$.

Importantly, however, a large number of the peptides had no similarity to any known sequences, which highlights the uniqueness of ant venom and also the low number of available sequences in protein sequence databases. This problem has been encountered by other studies looking at hymenopteran venoms ${ }^{23}, 39,52$. Moreover, there was a lack of separation of the basic, low mass peptides especially those present in $N$. commutata venom; hence, the 2D-PAGE technique was unable to resolve the identity of these peptides resulting in the need to employ an alternative method for peptide characterisation.

\section{Ant Venom Peptidomes}

The venoms of ants and other hymenoptera are known sources of biologically active, low molecular weight peptides $3,53,54$. Unlike snakes, spiders, scorpions and marine cone snails ${ }^{37}$, 55-57, most ant venom peptidomes remain barely explored. Accordingly, the present study represents the first in-depth study of a range of ant venom peptides using highly sensitive MS technologies.

MALDI Matrix Optimisation. Numerous matrix candidates have been evaluated but CHCA has become the favoured matrix for the analysis of peptides ${ }^{58-61}$. Our results 
confirmed recent reports that different matrices yield different spectra in MALDI-TOF MS ${ }^{62}$, 63. We found that CHCA and FA matrices gave the highest peptide counts with the broadest mass distribution, which is in accord with previous studies ${ }^{38}$. Moreover, the range of peptides detected by the two matrices revealed that FA was most suited for poneroid ant venoms and was slightly more effective at detecting low mass peptides < 1800 Da in formicoid venoms, whilst CHCA was better at detecting peptides in formicoid venoms with a wider distribution of masses, e.g. E. tuberculatum and M. gulosa (Fig. 7 and 8). It was also determined that FA resulted in the formation of fewer adducts compared to CHCA (Fig. 3B) as has been previously reported ${ }^{64}$. This is most likely due to its increased tolerance to salts and other impurities ${ }^{65}$. Nevertheless, a consistent difference in signal intensity was noted which has been reported to be higher with $\mathrm{CHCA}^{65}$.

Ant Venom Peptide numbers and Distribution. The presence of higher abundance peptides and proteins in the sample, results in undetected or unresolved signals from quasiisobaric peptides and lower abundance peptide components. Accordingly, ant venoms were subjected to RP-HPLC separation prior to MALDI-TOF MS, revealing a complex mixture of peptides due to the separation and thus increased detection of trace levels of peptides. In addition, this overcame the ion suppression phenomenon by reducing the number of coionised peptides in the mass spectrometer source 37,66 .

The different ant venoms did not follow the same mass distribution, reflecting their peptide diversity. This is not unique to ants, as both bimodal ${ }^{37}$ and unimodal ${ }^{67}$ distributions have been previously reported with other venoms. Most of the ant venoms analysed have the majority of their peptides in the low molecular weight range (1-4 kDa). This suggests that ant venoms have peptides that are overall smaller than the peptidic component of other venomous animals such as scorpions $(4-5 \mathrm{kDa})^{68}$, sea anemones $(2-3.5 \mathrm{kDa})^{69}$ and 
spiders $(3-5 \mathrm{kDa} \text { and } 6.5-8.5 \mathrm{kDa})^{70}$ but not marine cone snails $(0.5-3.5 \mathrm{kDa})^{55}$. However, formicoid ant venoms seem to be more complex than poneroid ant venoms and possess some larger peptides with masses up to $8 \mathrm{kDa}$. These results confirm the conclusions of previous studies about ant venom peptides using lower resolution MALDI-TOF MS than the present study ${ }^{38,53}$. However, we found that the poneroid ant $N$. apicalis has a complex venom despite the fact that it is a highly specialised predator of only Syntermes termites ${ }^{71}$. Its venom complexity is comparable to some spider and cone snail venoms ${ }^{55,72}$. This suggests that predation is not the primary factor in venom composition, and that defence against predators and pathogens may play a larger role in the diversification of ant venom toxins.

Given the paucity of data on ant venom peptides, the present study highlights that the enormous biodiversity of ant venoms remains almost completely unexplored. If one assumes each species of ant has on average 600 unique venom peptides (average of the six ant venoms), the total biodiversity present from around 9000 species (ca. $70 \%$ of the total 13,000 extant species) of venomous ants in the world is ca. 5,400,000 distinct peptides (Aili et al., 2014). Thus, ant venoms represent an enormous pharmacological library that is significantly larger than scorpions (ca. 100,000 peptides) ${ }^{57}$ and marine cone snail venoms (ca. 500,000 peptides) ${ }^{55}$ but is comparable to that of spiders (ca. $10,000,000$ peptides) ${ }^{37}$. Of course, this fails to account for common peptide masses across all species (Fig. 8). Hence a more conservative estimation of ant venom peptide biodiversity is around $2,000,000+$ peptides. To place this potential resource in perspective, only 75 peptides from the enormous chemical library of ant venom peptidomes have been described to date, representing a mere $0.003 \%$. 
Disulfide-bonded Venom Peptides. Disulfide bonds render peptides very stable and resistant to a number of proteases and environmental extremes ${ }^{28,}{ }^{73}$. This is an advantageous feature and consequently has become a focus in the search for stable therapeutic or insecticidal peptide toxins ${ }^{28,73}$. Indeed, all eight venom-derived drugs on the pharmaceutical drug market contain between 1-14 disulfide bonds ${ }^{73}$. Furthermore, other venomous animals such as cone snails, scorpions and spiders contain a high proportion of disulfide rich peptides ${ }^{37,73-75}$. While the present study confirms previous findings that ant venom is believed to be a rich source of small linear peptides ${ }^{53}$, disulfide-bonded peptides are minor components of ant peptidomes. However, biological activities and functions of these reticulated peptides still remain unknown and should be investigated in future studies as potential sources of insecticides.

\section{CONCLUDING REMARKS}

This proteomic-based study has revealed not only the vast complexity of ant venom proteins and peptides but also their inter- and intra-family variation. The mass range of ant venom peptides, particularly those from poneroid ants, is lower than that of peptides from other venoms, indicating likely novel structures and pharmacologies. The peptide mass distributions varied across ant clades and between different ant genera from the same clade, reflecting their peptide diversity. Also given that some ant venoms were complex despite only preying upon one prey species suggest that there are likely a wide variety of bioactive molecules involved in predator defence, communication and host defence against infection. This peptide diversity highlights the utility of ant venoms as novel chemical peptide libraries with the potential to be sources of novel therapeutic or insecticide leads. 


\section{ASSOCIATED CONTENT}

\section{Supporting Information}

Methodology for the identification of disulphide-bonded peptides as well as annotated spectra from 2D gel spots where a protein was identified from a single peptide have been included in the supporting information.

\begin{tabular}{|c|c|c|}
\hline Supplementary Figure S1 & $\begin{array}{l}\text { Identification of disulfide-bonded peptides with the } \\
\text { use of 1,5-DAN matrix. }\end{array}$ & Page S3 \\
\hline Supplementary Figure S2 & $\begin{array}{l}\text { Annotated MS spectra of a peptide from } N \text {. } \\
\text { commutata 2D gel spot } 2 \text { used to match against } \\
\text { Hymenopteran proteins. }\end{array}$ & Page S4 \\
\hline Supplementary Figure S3 & $\begin{array}{l}\text { Annotated MS spectra of a peptide from } N \text {. } \\
\text { commutata } 2 \mathrm{D} \text { gel spot } 5 \text { used to match against } \\
\text { Hymenopteran proteins. }\end{array}$ & Page S5 \\
\hline Supplementary Figure S4 & $\begin{array}{l}\text { Annotated MS spectra of a peptide from } N \text {. } \\
\text { commutata } 2 \mathrm{D} \text { gel spot } 8 \text { used to match against } \\
\text { Hymenopteran proteins. }\end{array}$ & Page S6 \\
\hline Supplementary Figure S5 & $\begin{array}{l}\text { Annotated MS spectra of a peptide from } N \text {. } \\
\text { commutata } 2 \mathrm{D} \text { gel spot } 10 \text { used to match against } \\
\text { Hymenopteran proteins. }\end{array}$ & Page S7 \\
\hline Supplementary Figure S6 & $\begin{array}{l}\text { Annotated MS spectra of a peptide from } N \text {. } \\
\text { commutata 2D gel spot } 15 \text { used to match against } \\
\text { Hymenopteran proteins. }\end{array}$ & Page S8 \\
\hline Supplementary Figure S7 & $\begin{array}{l}\text { Annotated MS spectra of a peptide from } N \text {. } \\
\text { commutata } 2 \mathrm{D} \text { gel spot } 17 \text { used to match against } \\
\text { Hymenopteran proteins. }\end{array}$ & Page S9 \\
\hline Supplementary Figure S8 & $\begin{array}{l}\text { Annotated MS spectra of the two peptides from } \mathrm{N} \text {. } \\
\text { commutata 2D gel spot } 18 \text { used to match against } \\
\text { Hymenopteran proteins. }\end{array}$ & Page S10 \\
\hline Supplementary Figure S9 & $\begin{array}{l}\text { Annotated MS spectra of a peptide from } N \text {. } \\
\text { commutata 2D gel spot } 19 \text { used to match against } \\
\text { Hymenopteran proteins. }\end{array}$ & Page S11 \\
\hline Supplementary Figure S10 & $\begin{array}{l}\text { Annotated MS spectra of a peptide from } N \text {. } \\
\text { commutata } 2 \mathrm{D} \text { gel spot } 23 \text { used to match against } \\
\text { Hymenopteran proteins. }\end{array}$ & Page S12 \\
\hline Supplementary Figure S11 & $\begin{array}{l}\text { Annotated MS spectra of a peptide from } N \text {. } \\
\text { commutata } 2 \mathrm{D} \text { gel spot } 24 \text { used to match against } \\
\text { Hymenopteran proteins. }\end{array}$ & Page S13 \\
\hline Supplementary Figure S12 & $\begin{array}{l}\text { Annotated MS spectra of a peptide from } E \text {. } \\
\text { tuberculatum 2D gel spot } 1 \text { used to match against } \\
\text { Hymenopteran proteins. }\end{array}$ & Page S14 \\
\hline Supplementary Figure S13 & $\begin{array}{l}\text { Annotated MS spectra of a peptide from } E \text {. } \\
\text { tuberculatum 2D gel spot } 2 \text { used to match against } \\
\text { Hymenopteran proteins. }\end{array}$ & Page S15 \\
\hline Supplementary Figure S14 & $\begin{array}{l}\text { Annotated MS spectra of the two peptides from } E \text {. } \\
\text { tuberculatum 2D gel spot } 13 \text { used to match against }\end{array}$ & Page S16 \\
\hline
\end{tabular}




\begin{tabular}{|l|l|l|}
\hline & Hymenopteran proteins. & Page S17 \\
\hline Supplementary Figure S15 & $\begin{array}{l}\text { Annotated MS spectra of a peptide from } E . \\
\text { tuberculatum 2D gel spot 15 used to match against } \\
\text { Hymenopteran proteins. }\end{array}$ & Page S18 \\
\hline Supplementary Figure S16 & $\begin{array}{l}\text { Annotated MS spectra of a peptide from } E . \\
\text { tuberculatum 2D gel spot 19 used to match against } \\
\text { Hymenopteran proteins. }\end{array}$ & \\
\hline
\end{tabular}

\section{ACKNOWLEDGEMENTS}

Financial support for this study was provided by an Australian Postgraduate Award to Samira

R. Aili, the Programme Convergence 2007-2013, Région Guyane from the European Community (BI-Appli, 115/SGAR-DE/2011/052274) to Alain Dejean and an Investissement d'Avenir grant managed by the Agence Nationale de la Recherche (CEBA, ANR-10-LABX-2501).

\section{ABBREVIATIONS}

ACN, acetonitrile; C7BzO, 3-(4-heptyl)phenyl-3-hydroxypropyl) dimethylammoniopropane sulfonate; 1,5-DAN, 1,5-diaminonapthalene; CHCA, $\alpha$-cyano-4-hydroxycinnamic acid; FA, ferulic acid; HGD, Hymenopteran Genome Database; IEF, isoelectric focussing; ionic CHCA, $\mathrm{N}$-tert-butyl-N-isopropyl-N-methylammonium $\quad \alpha$-cyano-4-hydroxycinnamate; IPG, immobilized $\mathrm{pH}$ gradient, LC-ESI-QTOF MS, liquid chromatography electrospray ionization quadrupole time-of-flight mass spectrometry; MALDI-TOF MS, matrix-assisted laserdesorption ionization time-of-flight mass spectrometry; PLA 2 , phospholipase $A_{2}$; RP-HPLC, reverse-phase high pressure liquid chromatography; SDS-PAGE, sodium dodecyl sulphate polyacrylamide gel electrophoresis; TFA, trifluoroacetic acid. 


\section{REFERENCES}

1. Windley, M. J.; Herzig, V.; Dziemborowicz, S. A.; Hardy, M. C.; King, G. F.; Nicholson, G. M., Spider-venom peptides as bioinsecticides. Toxins (Basel) 2012, 4, (3), 191-227.

2. Coddington, J. A.; Levi, H. W., Systematics and evolution of spiders (Araneae). Annu. Rev. Ecol. Syst. 1991, 22, (1), 565-592.

3. Aili, S. R.; Touchard, A.; Escoubas, P.; Padula, M. P.; Orivel, J.; Dejean, A.; Nicholson, G. M., Diversity of peptide toxins from stinging ant venoms. Toxicon 2014, 92, 166-78.

4. Touchard, A.; Aili, S.; Fox, E.; Escoubas, P.; Orivel, J.; Nicholson, G.; Dejean, A., The biochemical toxin arsenal from ant venoms. Toxins (Basel) 2016, 8, (1), 30.

5. Johnson, S. R.; Copello, J. A.; Evans, M. S.; Suarez, A. V., A biochemical characterization of the major peptides from the venom of the giant neotropical hunting ant Dinoponera australis. Toxicon 2010, 55, (4), 702-10.

6. Rifflet, A.; Gavalda, S.; Téné, N.; Orivel, J.; Leprince, J.; Guilhaudis, L.; Génin, E.; Vétillard, A.; Treilhou, M., Identification and characterization of a novel antimicrobial peptide from the venom of the ant Tetramorium bicarinatum. Peptides 2012, 38, (2), 363-370.

7. AntWeb, Available online: http://www. antweb.org (accessed on 27 August 2014) 2014.

8. Lach, L.; Parr, C. L.; Abott, K. L., Ant ecology. Oxford University Press: 2010.

9. Ward, P. S., Taxonomy, phylogenetics, and evolution. In 2010; Vol. 1.

10. Cerdá, X.; Dejean, A., Predation by ants on arthropods and other animals. In Predation in the Hymenoptera: an Evolutionary Perspective, Polidori, C., Ed. Transworld Research Network: Kerala - India, 2011; pp 39-78.

11. Orivel, J.; Redeker, V.; Le Caer, J. P.; Krier, F.; Revol-Junelles, A. M.; Longeon, A.; Chaffotte, A.; Dejean, A.; Rossier, J., Ponericins, new antibacterial and insecticidal peptides from the venom of the ant Pachycondyla goeldii. J. Biol. Chem. 2001, 276, (21), 17823-9.

12. Wilson, E. O., Success and Dominance in Ecosystems: The Case of the Social Insects. Ecology Institute: Oldendorf/Luhe, Germany, 1990; Vol. 2.

13. Ebaid, H.; Al-Khalifa, M.; Isa, A. M.; Gadoa, S., Bioactivity of Samsum ant (Pachycondyla sennaarensis) venom against lipopolysaccharides through antioxidant and upregulation of Akt1 signaling in rats. Lipids Health Dis. 2012, 11, (1), 93.

14. Inagaki, H.; Akagi, M.; Imai, H. T.; Taylor, R. W.; Wiese, M. D.; Davies, N. W.; Kubo, T., Pilosulin 5, a novel histamine-releasing peptide of the Australian ant, Myrmecia pilosula (Jack Jumper Ant). Arch. Biochem. Biophys. 2008, 477, (2), 411-416.

15. dos Santos Pinto, J. R.; Fox, E. G.; Saidemberg, D. M.; Santos, L. D.; da Silva Menegasso, A. R.; Costa-Manso, E.; Machado, E. A.; Bueno, O. C.; Palma, M. S., Proteomic view of the venom from the fire ant Solenopsis invicta Buren. J. Proteome Res. 2012, 11, (9), 4643-4653.

16. Wiese, M. D.; Brown, S. G.; Chataway, T. K.; Davies, N. W.; Milne, R. W.; Aulfrey, S. J.; Heddle, R. J., Myrmecia pilosula (Jack Jumper) ant venom: identification of allergens and revised nomenclature. Allergy 2007, 62, (4), 437-43.

17. Hink, W. F.; Pappas, P. W.; Jaworski, D. C., Partial biochemical characterization of venom from the ant, Pseudomyrmex triplarinus. Toxicon 1994, 32, (7), 763-72.

18. Pan, J.; Hink, W. F., Isolation and characterization of myrmexins, six isoforms of venom proteins with anti-inflammatory activity from the tropical ant, Pseudomyrmex triplarinus. Toxicon 2000, $38,(10), 1403-13$.

19. Haddad Junior, V.; Cardoso, J. L. C.; Moraes, R. H. P., Description of an injury in a human caused by a false tocandira (Dinoponera gigantea, Perty, 1833) with a revision on folkloric, pharmacological and clinical aspects of the giant ants of the genera Paraponera and Dinoponera (sub-family Ponerinae). Rev. Inst. Med. Trop. Sao Paulo 2005, 47, (4), 235-238. 
20. Piek, T.; Duval, A.; Hue, B.; Karst, H.; Lapied, B.; Mantel, P.; Nakajima, T.; Pelhate, M.; Schmidt, J. O., Poneratoxin, a novel peptide neurotoxin from the venom of the ant, Paraponera clavata. Comp. Biochem. Physiol., C: Comp. Pharmacol. 1991, 99, (3), 487-495.

21. Johnson, S. R.; Rikli, H. G.; Schmidt, J. O.; Evans, M. S., A reexamination of poneratoxin from the venom of the bullet ant Paraponera clavata. Peptides 2016.

22. Pluzhnikov, K.; Nosyreva, E.; Shevchenko, L.; Kokoz, Y.; Schmalz, D.; Hucho, F.; Grishin, E., Analysis of ectatomin action on cell membranes. Eur. J. Biochem. 1999, 262, (2), 501-6.

23. Torres, A. F. C.; Huang, C.; Chong, C.-M.; Leung, S. W.; Prieto-da-Silva, A. R. B.; Havt, A.; Quinet, Y. P.; Martins, A. M. C.; Lee, S. M. Y.; Rádis-Baptista, G., Transcriptome analysis in venom gland of the predatory giant ant Dinoponera quadriceps: insights into the polypeptide toxin arsenal of Hymenopterans. PLoS One 2014, 9, (1), e87556.

24. Gonçalves Paterson Fox, E.; Russ Solis, D.; Delazari Dos Santos, L.; Aparecido Dos Santos Pinto, J. R.; Ribeiro da Silva Menegasso, A.; Cardoso Maciel Costa Silva, R.; Sergio Palma, M.; Correa Bueno, O.; de Alcantara Machado, E., A simple, rapid method for the extraction of whole fire ant venom (Insecta: Formicidae: Solenopsis). Toxicon 2013, 65, 5-8.

25. Escoubas, P.; King, G. F., Venomics as a drug discovery platform. Expert Rev. Proteomics 2009.

26. Vetter, I.; Davis, J. L.; Rash, L. D.; Anangi, R.; Mobli, M.; Alewood, P. F.; Lewis, R. J.; King, G. F., Venomics: a new paradigm for natural products-based drug discovery. Amino Acids 2011, 40, (1), 15-28.

27. Nolde, D. E.; Sobol, A. G.; Pluzhnikov, K. A.; Grishin, E. V.; Arseniev, A. S., Three-dimensional structure of ectatomin from Ectatomma tuberculatum ant venom. J. Biomol. NMR 1995, 5, (1), 1-13.

28. Saez, N. J.; Senff, S.; Jensen, J. E.; Er, S. Y.; Herzig, V.; Rash, L. D.; King, G. F., Spider-venom peptides as therapeutics. Toxins (Basel) 2010, 2, (12), 2851-2871.

29. King, G. F.; Hardy, M. C., Spider-venom peptides: structure, pharmacology, and potential for control of insect pests. Annu. Rev. Entomol. 2013, 58, (1), 475-96.

30. Deutscher, A. T.; Jenkins, C.; Minion, F. C.; Seymour, L. M.; Padula, M. P.; Dixon, N. E.; Walker, M. J.; Djordjevic, S. P., Repeat regions R1 and R2 in the P97 paralogue Mhp271 of Mycoplasma hyopneumoniae bind heparin, fibronectin and porcine cilia. Mol. Microbiol. 2010, 78, (2), 444458.

31. Jobbins, S. E.; Hill, C. J.; D’Souza-Basseal, J. M.; Padula, M. P.; Herbert, B. R.; Krockenberger, M. B., Immunoproteomic approach to elucidating the pathogenesis of cryptococcosis caused by Cryptococcus gattii. J. Proteome Res. 2010, 9, (8), 3832-3841.

32. Raymond, B. B. A.; Tacchi, J. L.; Jarocki, V. M.; Minion, F. C.; Padula, M. P.; Djordjevic, S. P., P159 from Mycoplasma hyopneumoniae binds porcine cilia and heparin and Is cleaved in a manner akin to ectodomain shedding. J. Proteome Res. 2013, 12, (12), 5891-5903.

33. Perkins, D. N.; Pappin, D. J. C.; Creasy, D. M.; Cottrell, J. S., Probability-based protein identification by searching sequence databases using mass spectrometry data. Electrophoresis 1999, 20, (18), 3551-3567.

34. Jaskolla, T. W.; Karas, M.; Roth, U.; Steinert, K.; Menzel, C.; Reihs, K., Comparison between vacuum sublimed matrices and conventional dried droplet preparation in MALDI-TOF mass spectrometry. J. Am. Soc. Mass. Spectrom. 2009, 20, (6), 1104-1114.

35. Escoubas, P.; Sollod, B.; King, G. F., Venom landscapes: mining the complexity of spider venoms via a combined cDNA and mass spectrometric approach. Toxicon 2006, 47, (6), 650-663.

36. Fukuyama, Y.; Iwamoto, S.; Tanaka, K., Rapid sequencing and disulfide mapping of peptides containing disulfide bonds by using 1, 5-diaminonaphthalene as a reductive matrix. J. Mass Spectrom. 2006, 41, (2), 191-201.

37. Palagi, A.; Koh, J. M.; Leblanc, M.; Wilson, D.; Dutertre, S.; King, G. F.; Nicholson, G. M.; Escoubas, P., Unravelling the complex venom landscapes of lethal Australian funnel-web spiders (Hexathelidae: Atracinae) using LC-MALDI-TOF mass spectrometry. J. Proteomics 2013, 80, 292310. 
38. Touchard, A.; Dauvois, M.; Arguel, M.-J.; Petitclerc, F.; Leblanc, M.; Dejean, A.; Orivel, J.; Nicholson, G. M.; Escoubas, P., Elucidation of the unexplored biodiversity of ant venom peptidomes via MALDI-TOF mass spectrometry and its application for chemotaxonomy. $J$. Proteomics 2014.

39. Bouzid, W.; Klopp, C.; Verdenaud, M.; Ducancel, F.; Vetillard, A., Profiling the venom gland transcriptome of Tetramorium bicarinatum (Hymenoptera: Formicidae): the first transcriptome analysis of an ant species. Toxicon 2013, 70, 70-81.

40. Leluk, J.; Schmidt, J.; Jones, D., Comparative studies on the protein composition of hymenopteran venom reservoirs. Toxicon 1989, 27, (1), 105-114.

41. Peiren, N.; de Graaf, D. C.; Vanrobaeys, F.; Danneels, E. L.; Devreese, B.; Van Beeumen, J.; Jacobs, F. J., Proteomic analysis of the honey bee worker venom gland focusing on the mechanisms of protection against tissue damage. Toxicon 2008, 52, (1), 72-83.

42. King, T. P.; Spangfort, M. D., Structure and biology of stinging insect venom allergens. Int. Arch. Allergy Immunol. 2000, 123, (2), 99-106.

43. Wanstall, J. C.; De la Lande, I., Fractionation of bulldog ant venom. Toxicon 1974, 12, (6), 649IN16.

44. Bonasio, R.; Zhang, G.; Ye, C.; Mutti, N. S.; Fang, X.; Qin, N.; Donahue, G.; Yang, P.; Li, Q.; Li, C.; Zhang, P.; Huang, Z.; Berger, S. L.; Reinberg, D.; Wang, J.; Liebig, J., Genomic comparison of the ants Camponotus floridanus and Harpegnathos saltator. Science 2010, 329, (5995), 1068-71.

45. Resende, V. M. F.; Vasilj, A.; Santos, K. S.; Palma, M. S.; Shevchenko, A., Proteome and phosphoproteome of Africanized and European honeybee venoms. Proteomics 2013, 13, (17), 2638-2648.

46. Hoffman, D. R., Allergens in bee venom: III. Identification of allergen B of bee venom as an acid phosphatase. J. Allergy Clin. Immunol. 1977, 59, (5), 364-366.

47. Li, R.; Zhang, L.; Fang, Y.; Han, B.; Lu, X.; Zhou, T.; Feng, M.; Li, J., Proteome and phosphoproteome analysis of honeybee (Apis mellifera) venom collected from electrical stimulation and manual extraction of the venom gland. BMC Genomics 2013, 14, 766.

48. Kheyri, H.; Cribb, B. W.; Merritt, D. J., Comparing the secretory pathway in honeybee venom and hypopharyngeal glands. Arthropod Struct. Dev. 2013, 42, (2), 107-114.

49. do Amaral, J. B.; Machado-Santelli, G. M., Salivary system in leaf-cutting ants (Atta sexdens rubropilosa Forel, 1908) castes: A confocal study. Micron 2008, 39, (8), 1222-1227.

50. Merzendorfer, H.; Zimoch, L., Chitin metabolism in insects: structure, function and regulation of chitin synthases and chitinases. J. Exp. Biol. 2003, 206, (Pt 24), 4393-412.

51. Mori, H.; Lee, J.-H.; Okuyama, M.; Nishimoto, M.; Ohguchi, M.; Kim, D.; Kimura, A.; Chiba, S., Catalytic reaction mechanism based on alpha-secondary deuterium isotope effects in hydrolysis of trehalose by European honeybee trehalase. Biosci. Biotechnol. Biochem. 2009, 73, (11), 24662473.

52. Sookrung, N.; Wong-din-Dam, S.; Tungtrongchitr, A.; Reamtong, O.; Indrawattana, N.; Sakolvaree, Y.; Visitsunthorn, N.; Manuyakorn, W.; Chaicumpa, W., Proteome and allergenome of Asian wasp, Vespa affinis, venom and IgE reactivity of the venom components. J. Proteome Res. 2014, 13, (3), 1336-44.

53. Touchard, A.; Koh, J.; Aili, S. R.; Dejean, A.; Nicholson, G. M.; Orivel, J.; Escoubas, P., The complexity and structural diversity of ant venom peptidomes is revealed by mass spectrometry profiling. Rapid Commun. Mass Spectrom. 2015, 29, (5), 385-396.

54. Wiese, M. D.; Chataway, T. K.; Davies, N. W.; Milne, R. W.; Brown, S. G.; Gai, W. P.; Heddle, R. J., Proteomic analysis of Myrmecia pilosula (jack jumper) ant venom. Toxicon 2006, 47, (2), 208-17.

55. Davis, J.; Jones, A.; Lewis, R. J., Remarkable inter- and intra-species complexity of conotoxins revealed by LC/MS. Peptides 2009, 30, (7), 1222-1227.

56. Escoubas, P.; Quinton, L.; Nicholson, G. M., Venomics: unravelling the complexity of animal venoms with mass spectrometry. J. Mass Spectrom. 2008, 43, (3), 279-295. 
57. Possani, L. D.; Becerril, B.; Delepierre, M.; Tytgat, J., Scorpion toxins specific for $\mathrm{Na}^{+}$channels. Eur. J. Biochem. 1999, 264, (2), 287-300.

58. Řehulková, H.; Chalupová, J.; Šebela, M.; Řehulka, P., A convenient purification and preconcentration of peptides with $\alpha$-cyano-4-hydroxycinnamic acid matrix crystals in a pipette tip for matrix-assisted laser desorption/ionization mass spectrometry. J. Mass Spectrom. 2010, 45, (1), 104-111.

59. Kouvonen, P.; Rainio, E. M.; Suni, V.; Koskinen, P.; Corthals, G. L., Data combination from multiple matrix-assisted laser desorption/ionization (MALDI) matrices: opportunities and limitations for MALDI analysis. Rapid Commun. Mass Spectrom. 2010, 24, (23), 3493-3495.

60. Ahn, S. H.; Park, K. M.; Bae, Y. J.; Kim, M. S., Quantitative reproducibility of mass spectra in matrix-assisted laser desorption ionization and unraveling of the mechanism for gas-phase peptide ion formation. J. Mass Spectrom. 2013, 48, (3), 299-305.

61. Rappsilber, J.; Moniatte, M.; Nielsen, M. L.; Podtelejnikov, A. V.; Mann, M., Experiences and perspectives of MALDI MS and MS/MS in proteomic research. Int. J. Mass spectrom. 2003, 226, (1), 223-237.

62. Matysiak, J.; Schmelzer, C. E.; Neubert, R. H.; Kokot, Z. J., Characterization of honeybee venom by MALDI-TOF and nanoESI-QqTOF mass spectrometry. J. Pharm. Biomed. Anal. 2011, 54, (2), 273-278.

63. Lai, Y.-H.; Wang, C.-C.; Chen, C. W.; Liu, B.-H.; Lin, S. H.; Lee, Y. T.; Wang, Y.-S., Analysis of initial reactions of MALDI based on chemical properties of matrixes and excitation condition. J. Phys. Chem. B 2012, 116, (32), 9635-9643.

64. Yang, H.; Wan, D.; Song, F.; Liu, Z.; Liu, S., $\alpha$-Cyano-4-hydroxycinnamic acid, sinapinic acid, and ferulic acid as matrices and alkylating agents for matrix-assisted laser desorption/ionization time-of-flight mass spectrometric analysis of cysteine-containing peptides. Rapid Commun. Mass Spectrom. 2013, 27, (12), 1410-1412.

65. Beavis, R.; Chaudhary, T.; Chait, B., $\alpha$-Cyano-4-hydroxycinnamic acid as a matrix for matrixassisted laser desorption mass spectromtry. Org. Mass Spectrom. 1992, 27, (2), 156-158.

66. Trimpin, S.; Wang, B.; Lietz, C. B.; Marshall, D. D.; Richards, A. L.; Inutan, E. D., New ionization processes and applications for use in mass spectrometry. Crit. Rev. Biochem. Mol. Biol. 2013, 48, (5), 409-429.

67. Abdel-Rahman, M. A.; Quintero-Hernandez, V.; Possani, L. D., Venom proteomic and venomous glands transcriptomic analysis of the Egyptian scorpion Scorpio maurus palmatus (Arachnida: Scorpionidae). Toxicon 2013, 74, 193-207.

68. Martin-Eauclaire, M.-F.; Céard, B.; Belghazi, M.; Lebrun, R.; Bougis, P. E., Characterization of the first $\mathrm{K}^{+}$channel blockers from the venom of the Moroccan scorpion Buthus occitanus Paris. Toxicon 2013, 75, 168-176.

69. Rodriguez, A. A.; Staendker, L.; Zaharenko, A. J.; Garateix, A. G.; Forssmann, W.-G.; Beress, L.; Valdes, O.; Hernandez, Y.; Laguna, A., Combining multidimensional liquid chromatography and MALDI-TOF-MS for the fingerprint analysis of secreted peptides from the unexplored sea anemone species Phymanthus crucifer. J. Chromatogr. B 2012, 903, 30-39.

70. Nicholson, G. M., Spider Venom Peptides. In Handbook of Biologically Active Peptides, 2 ed.; Kastin, A. J., Ed. Academic press: San Diego, 2013.

71. Mill, A. E., Predation by the ponerine ant Pachycondyla commutata on termites of the genus Syntermes in Amazonian rain forest. J. Nat. History 1984, 18, (3), 405-410.

72. Escoubas, P., Molecular diversification in spider venoms: a web of combinatorial peptide libraries. Mol. Divers. 2006, 10, (4), 545-554.

73. King, G. F., Venoms as a platform for human drugs: translating toxins into therapeutics. Expert Opin. Biol. Ther. 2011, 11, (11), 1469-1484.

74. Palma, M. S., Peptides as toxins/defensins. Amino Acids 2011, 40, (1), 1-4. 
75. Quinton, L.; Demeure, K.; Dobson, R.; Gilles, N.; Gabelica, V.; De Pauw, E., New method for characterizing highly disulfide-bridged peptides in complex mixtures: application to toxin identification from crude venoms. J. Proteome Res. 2007, 6, (8), 3216-3223.

76. Gasteiger, E.; Gattiker, A.; Hoogland, C.; Ivanyi, I.; Appel, R. D.; Bairoch, A., ExPASy: the proteomics server for in-depth protein knowledge and analysis. Nucleic Acids Res. 2003, 31, (13), 3784-3788. 
Table 1. Protein assignment of $\boldsymbol{N}$. commutata venom 2D-PAGE spots identified by nanoLC-ESI-QTOF MS/MS.

\begin{tabular}{|c|c|c|c|c|c|c|c|}
\hline $\begin{array}{c}\text { 2D Gel } \\
\text { spot }\end{array}$ & *Protein ID & Organism & $\begin{array}{l}\text { UniProt } \\
\text { Accession } \\
\text { Number }\end{array}$ & $\begin{array}{c}\text { Theoretical } \\
\text { MW (Da) } \\
\text { and pl }\end{array}$ & $\begin{array}{l}\text { Observed } \\
\text { MW (Da) } \\
\text { and pl }\end{array}$ & $\begin{array}{c}\text { Coverage and } \\
\text { score } \\
(-10 \operatorname{lgP})\end{array}$ & Peptide Sequence \\
\hline 1 & Actin-5C & Acromyrmex echinatior & EGI67274.1 & $\begin{array}{c}41822 \\
5.33\end{array}$ & $\begin{array}{c}38000 \\
9.8\end{array}$ & $\begin{array}{l}12 \% \\
90.4\end{array}$ & $\begin{array}{l}\text { 1108.04 DLYANTVLSGGTTMYPGIADR } \\
\text { 855.43 LC(+71.04)YVALDFEQEMATAASSSSLEK }\end{array}$ \\
\hline \multirow[b]{2}{*}{2} & Venom acid phosphatase & Camponotus floridanus & EFN60591 & $\begin{array}{c}41821.8 \\
5.30\end{array}$ & 11500 & $\begin{array}{c}4 \% \\
23.6\end{array}$ & $\begin{array}{l}\text { 911.52 LYLYSGHETNLASLLK } \\
443.80 \text { LFAGPLIR }\end{array}$ \\
\hline & Ponericin-G3 & Neoponera goeldii & P82416.1 & $\begin{array}{c}3383.0 \\
10.22\end{array}$ & 9.5 & $\begin{array}{c}27 \% \\
26.66\end{array}$ & 523.80 GWKDWLNK ${ }^{\#}$ \\
\hline 5 & Ponericin-G3 & Neoponera goeldii & P82416 & $\begin{array}{c}3383.0 \\
10.22\end{array}$ & $\begin{array}{c}<5000 \\
9.2\end{array}$ & $\begin{array}{l}27 \% \\
25.8\end{array}$ & 523.78 GWKDWLNK ${ }^{\#}$ \\
\hline 8 & TP53-regulating kinase & Acromyrmex echinatior & EGI66742.1 & $\begin{array}{c}27120.4 \\
9.36\end{array}$ & $\begin{array}{c}10000 \\
5.0\end{array}$ & $\begin{array}{c}4 \% \\
27.5\end{array}$ & $561.32 \mathrm{KQ}(+.98)$ YEQILAK ${ }^{\#}$ \\
\hline \multirow{2}{*}{10} & Venom acid phosphatase & Camponotus floridanus & EFN60591 & $\begin{array}{c}41821.8 \\
5.30\end{array}$ & 15000 & $\begin{array}{c}4 \% \\
23.6\end{array}$ & $\begin{array}{l}\text { 911.52 LYLYSGHETNLASLLK } \\
\text { 443.79 LFAGPLIR }\end{array}$ \\
\hline & Putative uncharacterized protein & Acromyrmex echinatior & F4WHI8 & $\begin{array}{l}18400.6 \\
6.06\end{array}$ & 5.5 & $\begin{array}{c}4 \% \\
23.2\end{array}$ & 421.76 TLENLPR ${ }^{\#}$ \\
\hline 13 & Actin-5, muscle-specific & Harpegnathos saltator & EFN78406 & $\begin{array}{c}41782.7 \\
5.30\end{array}$ & $\begin{array}{c}39000 \\
6.1\end{array}$ & $\begin{array}{c}26 \% \\
138.9\end{array}$ & $\begin{array}{l}\text { 977.57 VAPEEHPVLLTEAPLNPK } \\
\text { 895.96 SYELPDGQVITIGNER } \\
\text { 1114.54 DLYANNVLSGGTTMYPGIADR } \\
\text { 566.77 GYSFTTTAER } \\
\text { 758.41 IWHHTFYNELR } \\
\text { 599.87 AVFPSIVGRPR } \\
\text { 572.35 EITALAPSTIK }\end{array}$ \\
\hline 14 & $\begin{array}{l}\text { Testicular acid phosphatase-like } \\
\text { protein }\end{array}$ & Harpegnathos saltator & EFN78070 & $\begin{array}{l}46695.4 \\
5.75\end{array}$ & $\begin{array}{c}39000 \\
6.3\end{array}$ & $\begin{array}{c}7 \% \\
38.3\end{array}$ & $\begin{array}{l}\text { 430.79 LINVVFR } \\
\text { 1258.11 VDDKLLLSDEC(+71.04)PEYLN(+0.98)EYER }\end{array}$ \\
\hline 15 & Actin & Acromyrmex echinatior & EGI64684.1 & $\begin{array}{c}41773.9 \\
5.29\end{array}$ & $\begin{array}{c}39000 \\
6.5\end{array}$ & $\begin{array}{c}3 \% \\
43.9\end{array}$ & 599.89 AVFPSIVGRPR ${ }^{\#}$ \\
\hline 17 & Ponericin & Neoponera goeldii & P82416 & $\begin{array}{c}3383.0 \\
10.22\end{array}$ & $\begin{array}{c}10000 \\
9.7\end{array}$ & $\begin{array}{l}27 \% \\
26.7\end{array}$ & 523.80 GWKDWLNK ${ }^{\#}$ \\
\hline 18 & Ponericin & Neoponera goeldii & P82416 & $\begin{array}{c}3383.0 \\
10.22\end{array}$ & $\begin{array}{c}8000 \\
9.4\end{array}$ & $\begin{array}{l}27 \% \\
29.3\end{array}$ & 523.79 GWKDWLNK $\#$ \\
\hline
\end{tabular}




\begin{tabular}{|c|c|c|c|c|c|c|c|}
\hline & Uracil phosphoribosyltransferase & Nasonia vitripennis & K7IRF5 & $\begin{array}{l}29771.4 \\
7.53\end{array}$ & & $\begin{array}{c}4 \% \\
21.3\end{array}$ & 490.26 MGSADAATKK ${ }^{\#}$ \\
\hline 19 & Ponericin & Neoponera goeldii & P82416 & $\begin{array}{c}3383.0 \\
10.22\end{array}$ & $\begin{array}{c}9000 \\
9.6\end{array}$ & $\begin{array}{l}27 \% \\
33.0\end{array}$ & 523.78 GWKDWLNK $\#$ \\
\hline 20 & $\mathrm{PLA}_{2} 2.2$ & Apis mellifera & H9K6W6 & $\begin{array}{c}23582.7 \\
6.96\end{array}$ & $\begin{array}{c}26000 \\
9.6\end{array}$ & $\begin{array}{l}11 \% \\
41.4\end{array}$ & $\begin{array}{l}\text { 877.94 QMSSNLVADLEETCK } \\
\text { 590.34 SVLVADTTMSR }\end{array}$ \\
\hline 23 & Trehalase & Microplitis demolitor & W4VV04 & $\begin{array}{c}67322.0 \\
5.50\end{array}$ & $\begin{array}{c}49000 \\
6.3\end{array}$ & $\begin{array}{c}2 \% \\
41.8 \\
\end{array}$ & 676.41 SQPPLLIPMVEK ${ }^{\#}$ \\
\hline \multirow{3}{*}{24} & Arylsulfatase B & Harpegnathos saltator & EFN75189 & $\begin{array}{c}65573.1 \\
5.86\end{array}$ & & $\begin{array}{c}2 \% \\
48.6\end{array}$ & 577.87 GVAAIWSPLIK \# \\
\hline & Actin-5, muscle-specific & Harpegnathos saltator & EFN78406 & $\begin{array}{c}41782.7 \\
5.30\end{array}$ & $\begin{array}{c}39000 \\
5.9\end{array}$ & $\begin{array}{c}12 \% \\
121.2\end{array}$ & $\begin{array}{l}\text { 977.56 VAPEEHPVLLTEAPLNPK } \\
895.97 \text { SYELPDGQVITIGNER } \\
599.87 \text { AVFPSIVGRPR }\end{array}$ \\
\hline & $\begin{array}{l}\text { Testicular acid phosphatase-like } \\
\text { protein }\end{array}$ & Camponotus floridanus & EFN63831 & $\begin{array}{c}148847.4 \\
6.61\end{array}$ & & $\begin{array}{c}5 \% \\
41.4\end{array}$ & $\begin{array}{l}\text { 1258.08 VDDNLILTDEC(+71.04)PQ(+0.98)YLDEYER } \\
\text { 443.78 LFAGPLIR }\end{array}$ \\
\hline
\end{tabular}

* MS/MS peptide sequences were searched using PEAKS software against the NCBInr database restricted to Hymenopterans. Protein matches from the NCBInr database with the highest coverages are shown. Theoretical mass and pl were determined using Protparam in ExPASy ${ }^{76}$. $S$ Spectra for these sequences have been included in the Supporting Information for Publication as Supplementary Figures S2-S11. Spots with no matches: 3, 4, 6, 7, 9, 11, 12, 16, 21, 22, 25, 26. 
Table 2. Protein assignment of E. tuberculatum venom 2D-PAGE spots identified by nanoLC-ESI-QTOF MS/MS 


\begin{tabular}{|c|c|c|c|c|c|c|c|}
\hline $\begin{array}{l}\text { 2D gel } \\
\text { Spot }\end{array}$ & *Protein ID & Organism & $\begin{array}{c}\text { UniProt } \\
\text { Accession } \\
\text { Number }\end{array}$ & $\begin{array}{c}\text { Theoretical } \\
\text { MW (Da) } \\
\text { and pl }\end{array}$ & $\begin{array}{c}\text { Observed } \\
\mathrm{MW}(\mathrm{Da}) \\
\text { and pl }\end{array}$ & $\begin{array}{c}\text { Coverage } \\
\text { and score } \\
(-10 \operatorname{lgP})\end{array}$ & Peptide Sequence \\
\hline 1 & Uncharacterized protein & Apis mellifera & A0A088A5D5 & $\begin{array}{c}90811.8 \\
8.91\end{array}$ & $\begin{array}{c}14500 \\
7.5\end{array}$ & $\begin{array}{c}1 \% \\
24.4\end{array}$ & 578.34 IVNKVEVINK\# \\
\hline 2 & Phospholipase A2 (Fragment) & Harpegnathos saltator & E2BTD5 & $\begin{array}{c}12034.7 \\
8.01\end{array}$ & $\begin{array}{c}14800 \\
6.9\end{array}$ & $\begin{array}{l}13 \% \\
20.3\end{array}$ & 883.90 SACSCDAEFYNCLK \\
\hline 7 & Hypothetical protein EAI_10007 & Harpegnathos saltator & E2BJ69 & $\begin{array}{c}26958.7 \\
6.70\end{array}$ & $\begin{array}{c}22000 \\
9.9\end{array}$ & $\begin{array}{l}10 \% \\
56.3\end{array}$ & $\begin{array}{l}640.83 \text { YPLPLADGSGYK } \\
670.80 \text { GAMGCGPQETFR }\end{array}$ \\
\hline 13 & Venom acid phosphatase & Acromyrmex echinatior & $\begin{array}{l}\text { F4W5B2 } \\
\text { EZA53020.1 }\end{array}$ & $\begin{array}{c}25278.2 \\
6.85 \\
47041.5 \\
7.60\end{array}$ & $\begin{array}{c}38000 \\
6.5\end{array}$ & $\begin{array}{c}6 \% \\
22.1 \\
2 \% \\
30.4\end{array}$ & $\begin{array}{l}772.43 \text { IRALPEIKAYIEK } \\
\text { 423.77 } \text { LVNVVFR }^{\#}\end{array}$ \\
\hline 14 & Venom acid phosphatase & Cerapachys biroi & EZA53020.1 & $\begin{array}{c}47041.5 \\
7.60\end{array}$ & $\begin{array}{c}38000 \\
6.1\end{array}$ & $\begin{array}{c}3 \% \\
38.9\end{array}$ & $\begin{array}{l}\text { 423.77 LVNVVFR } \\
364.21 \text { LLYYR }\end{array}$ \\
\hline 15 & Venom acid phosphatase & Cerapachys biroi & EZA53020.1 & $\begin{array}{c}47041.5 \\
7.60\end{array}$ & $\begin{array}{c}39000 \\
6.0\end{array}$ & $\begin{array}{c}2 \% \\
33.2\end{array}$ & 423.77 LVNVVFR $^{\#}$ \\
\hline 17 & Endochitinase & Harpegnathos saltator & E2BB48 & $\begin{array}{c}52819.7 \\
6.08\end{array}$ & $\begin{array}{c}50000 \\
5.9\end{array}$ & $\begin{array}{c}6 \% \\
75.3\end{array}$ & $\begin{array}{l}\text { 739.85 NNFFYFVEELR } \\
\text { 543.84 LVVGIPLYGR }\end{array}$ \\
\hline 18 & Dipeptidyl peptidase 4 & Camponotus floridanus & E2AF09 & $\begin{array}{c}86583.9 \\
6.24\end{array}$ & $\begin{array}{c}75000 \\
8.0\end{array}$ & $\begin{array}{c}5 \% \\
71.9\end{array}$ & $\begin{array}{l}783.42 \text { VYYLATAPGEPTQR } \\
832.08 \mathrm{C}(+71.04) \text { GISVAPVTSWIYYDSIYTER }\end{array}$ \\
\hline 19 & Dipeptidyl peptidase 4 & Camponotus floridanus & E2AF09 & $\begin{array}{c}86583.9 \\
6.24\end{array}$ & $\begin{array}{c}75000 \\
7.8\end{array}$ & $\begin{array}{c}2 \% \\
56.6\end{array}$ & 783.41 VYYLATAPGEPTQR \\
\hline 20 & Dipeptidyl peptidase 4 & Camponotus floridanus & E2AF09 & $\begin{array}{c}86583.9 \\
6.24\end{array}$ & $\begin{array}{c}75000 \\
7.5\end{array}$ & $\begin{array}{c}5 \% \\
51.6\end{array}$ & $\begin{array}{l}\text { 783.41 VYYLATAPGEPTQR } \\
832.08 \mathrm{C}(+71.04) \text { GISVAPVTSWIYYDSIYTER }\end{array}$ \\
\hline 21 & Dipeptidyl peptidase 4 & Camponotus floridanus & E2AF09 & $\begin{array}{c}86583.9 \\
6.24\end{array}$ & $\begin{array}{c}75000 \\
7.2\end{array}$ & $\begin{array}{c}5 \% \\
72.5\end{array}$ & $\begin{array}{l}\text { 783.41 VYYLATAPGEPTQR } \\
1247.61 \text { CGISVAPVTSWIYYDSIYTER }\end{array}$ \\
\hline 22 & Dipeptidyl peptidase 4 & Camponotus floridanus & E2AF09 & $\begin{array}{c}86583.9 \\
6.24\end{array}$ & $\begin{array}{c}75000 \\
7 . .0\end{array}$ & $\begin{array}{c}5 \% \\
80.1 \\
\end{array}$ & $\begin{array}{l}\text { 832.01 C(+71.04)GISVAPVTSWIYYDSIYTER } \\
783.41 \text { VYYLATAPGEPTQR }\end{array}$ \\
\hline 23 & Dipeptidyl peptidase 4 & Camponotus floridanus & E2AF09 & $\begin{array}{c}86583.9 \\
6.24\end{array}$ & $\begin{array}{c}75000 \\
6.9\end{array}$ & $\begin{array}{c}5 \% \\
90.6\end{array}$ & $\begin{array}{l}\text { 783.41 VYYLATAPGEPTQR } \\
\text { 661.82 IYYDSIYTER } \\
\text { 832.08 C(+71.04)GISVAPVTSWIYYDSIYTER }\end{array}$ \\
\hline
\end{tabular}


696.39 YHIIADVEYIR

5.0

59.2

554.29 YVELANTAAR

646.65 SM(+15.99)LELGSSKPWPDAM(+15.99)EK

*MS/MS peptide sequences were searched using PEAKS software against the NCBInr database restricted to Hymenopterans. Protein matches from the NCBInr database with the highest coverages are shown. Theoretical mass and pl were determined using Protparam in ExPASy [75]. \# Spectra for these sequences have been included in the Supporting Information for Publication as Supplementary Figure S12-S16. Spots with no matches: 3, 4, 5, 6, 8-12, 16 and 24. 


\section{FIGURE LEGENDS}

Figure 1. 1D and 2D SDS-PAGE gels of representative ant venoms. (A) 1D gel showing molecular weight markers (MW), and reduced and alkylated $100 \mu \mathrm{g}$ samples of $\mathrm{N}$. commutata $(N c), N$. apicalis $(N a)$, O. hastatus $(O h)$, E. tuberculatum $(E t)$, E. brunneum $(E b)$ and $M$. gulosa $(M g)$. The red box highlights a conserved protein band across the six species. (B-C) 2D SDS-PAGE of reduced and alkylated N. commutata (B) and E. tuberculatum (C) whole venom. A $300 \mu \mathrm{g}$ sample of crude venom was subjected to isoelectric focusing on an $11 \mathrm{~cm} \mathrm{pH} \mathrm{3-10} \mathrm{IEF} \mathrm{strip.} \mathrm{All} \mathrm{gels} \mathrm{were} \mathrm{separated} \mathrm{by} \mathrm{a} \mathrm{Tris-glycine} \mathrm{(4-20 \% )} \mathrm{SDS-PAGE} \mathrm{and}$ stained with Flamingo. Protein spots (circled) were excised for identification by nanoLC-ESIQTOF MS/MS and de novo peptide sequencing.

Figure 2. RP-HPLC chromatograms of poneroid and formicoid ant venoms. Venoms were separated by analytical C18 RP-HPLC using an ACN/0.085\% TFA gradient of 1\%/min (grey dotted line) at $1 \mathrm{ml} / \mathrm{min}$. Panels show the chromatographic elution profile of venoms from the poneroid ants (A) N. commutata, (B) N. apicalis and (C) O. hastatus, and the formicoid ants (D) E. tuberculatum (E) E. brunneum and (F) M. gulosa. Note the different gradient in panel E for E. brunneum venom. Chromatographic peaks were monitored at 215 and $280 \mathrm{~nm}$ (only absorbance at $215 \mathrm{~nm}$ is shown for clarity). MALDI spectra of the numbered HPLC fractions (f) from N. commutata (Panel A) are shown in Fig. 4.

Figure 3. Number and distribution of E. tuberculatum venom peptides detected with different MALDI matrices. (A) Box-and-whisker plot depicting the mass distribution of peptides obtained with the different MALDI matrices; (B) Total peptide counts from all RPHPLC fractions using the matrices CHCA, FA, a combination of CHCA and FA, ionic CHCA and 1,5-DAN before, and after, removal of adducts, dimers and doubly charged species; (C) Boxand-whisker plot showing ranges of peptide masses determined by CHCA (cyan boxes) and FA (beige boxes) matrices from the six venoms. The bottom and top of each box in panels $A$ and $C$ represents the first and third quartiles, respectively, while the band and cross inside each box represents the median and mean masses, respectively. The ends of the whiskers represent the 5-95 percentile range while the closed circles represent masses outside the 595 percentile range. 
Figure 4. Representative MALDI-TOF MS spectra of $N$. commutata RP-HPLC fractions. MS Spectra were obtained in positive linear mode and fractions are labelled according to the RPHPLC chromatogram shown in Fig. $2 A$ as $f 10(A), f 4(B)$, and $f 21$ (C). Left-hand panels labelled ' $a$ ' with cyan shading were obtained using CHCA matrix, while right-hand panels labelled ' $b$ ' with beige shading were obtained using FA matrix.

Figure 5. LC-MALDI-TOF mass profile of the poneroid ants N. commutata, N. apicalis and $O$. hastatus. Histograms show the abundance of peptide masses in each venom sorted into 100 Da mass bins (columns; left-hand ordinate axis) and the cumulative total of peptide masses in each venom (circles; right-hand ordinate axis). Shaded areas represent 5-95\% of the total number of peptides. (Aa-Ca) Peptide masses obtained using CHCA matrix, (Aa) N. commutata, (Ba), N. apicalis and ( $\mathrm{Ca}$ ) O. hastatus. (Ab-Cb) Peptide masses obtained using FA matrix, (Ab) N. commutata, (Bb), N. apicalis and ( $\mathrm{Cb})$ O. hastatus. Total peptide counts are indicated in the upper right-hand corner of each panel. All lateral and front images of the ants investigated were taken by Ryan Perry and can be found at www.AntWeb.org.

Figure 6. LC-MALDI-TOF mass profile of the formicoid ants E. tuberculatum, E. brunneum and M. gulosa. Histograms show the abundance of peptide masses in each venom sorted into 100 Da mass bins (columns; left-hand ordinate axis) and the cumulative total of peptide masses in each venom (circles; right-hand ordinate axis). Shaded areas represent $5-95 \%$ of the total number of peptides. (Aa-Ca) Peptide masses obtained using CHCA matrix, (Aa) E. tuberculatum, (Ba) E. brunneum ( $\mathrm{Ca}$ ) M. gulosa. (Ab-Cb) Peptide masses obtained using FA matrix, (Ab) E. tuberculatum, (Bb) E. brunneum (Cb) M. gulosa. Total peptide counts are indicated in the upper right-hand corner of each panel. Lateral and front images of the ants investigated were taken by April Nobile, Estella Ortega, and Zach Lieberman and can be found at www.AntWeb.org.

Figure 7. Area-proportional Euler plots depicting numbers of shared and distinct peptides. Shared peptides were defined as being within \pm 1 Da. Spectra were acquired with CHCA (cyan) and FA (beige) MALDI matrices. The numbers within the circles indicate the number of unique peptides detected employing that particular matrix. The total number of peptides detected by each matrix is indicated in the box on the bottom of the Euler plots. Area- 
proportional Euler plots depicting overlapping peptide masses from multiple venoms were constructed using Venn diagram plotter.

Figure 8. (A) Cumulative total of peptides detected using CHCA (cyan circles) or FA (beige circles) from the poneroid ants $N$. commutata, $P$. apicalis and O. hastatus ( $A$ a) or formicoid ants $O$. hastatus, O. brunneum and $M$. gulosa (Ab). Panel Ab grey shaded area, FA was more efficient at detecting lower molecular weight peptides below $1800 \mathrm{Da}$ in the formicoid venoms. (B-C) Common peptides between ant clades. Area-proportional Euler plot depicting species variation in numbers of shared and distinct peptides ( \pm 1 Da) determined using MALDI-TOF MS. Left hand panels labelled 'a' contains data from poneroid ants; right hand panels labelled ' $b$ ' show a comparison of the formicoid ant data. Panels B refer to the venom peptides detected using CHCA matrix, while Panel $\mathrm{C}$ represents peptides detected using FA matrix.

Figure 9. Determination of disulfide-bonded peptides in ant venoms. MALDI-TOF MS analysis of individual RP-HPLC fractions from five ant venoms. (A-F) 2D Landscape plots where the abscissa represents the C18 RP-HPLC retention time while the ordinate shows the masses obtained by MALDI-TOF MS. Cyan circles represent the non-disulfide-bonded peptides in the venom. Red triangles indicate peptides with a disulfide bond. Total number of disulfidebonded peptides in each venom is indicated in the top right-hand box in each panel (S-S). (A) N. commutata, (B) N. apicalis, (C) O. hastatus, (D) E. tuberculatum, (F) E. brunneum and (F) M. gulosa. The shaded areas represent $5-95 \%$ of the total number of peptides. (G) Scatter dot plot showing all disulfide-bonded masses from each venom; the dotted horizontal line represents the mean mass of disulfide-bonded peptides while the solid bars represent the mass range. 


\section{FIGURES}

\section{Figure 1}

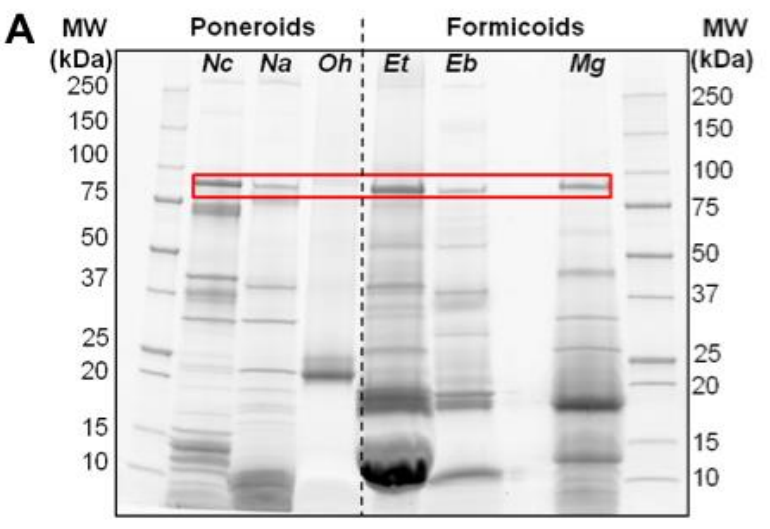

B Neoponera commutata

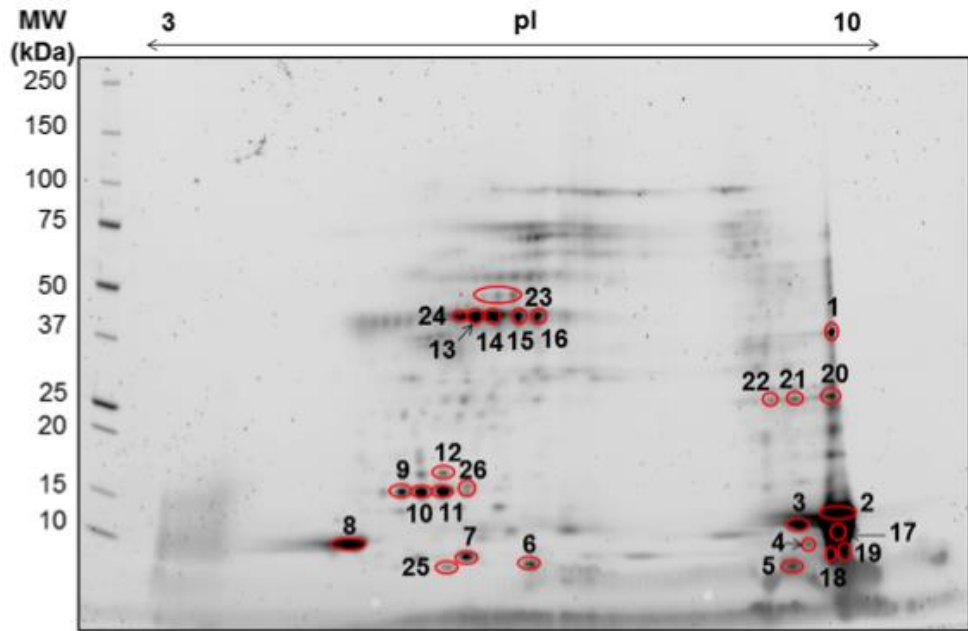

C Ectatomma tuberculatum

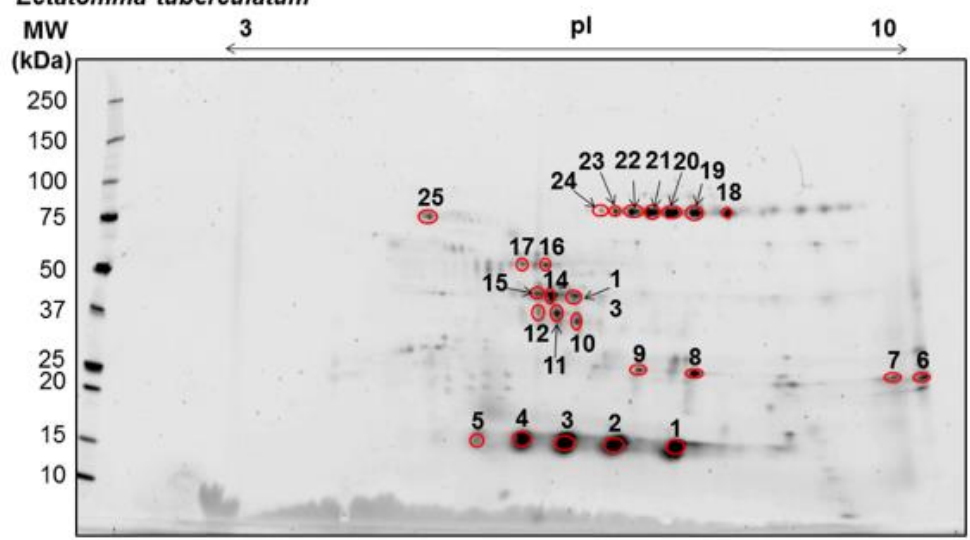


Figure 2

\section{Poneroids}

A

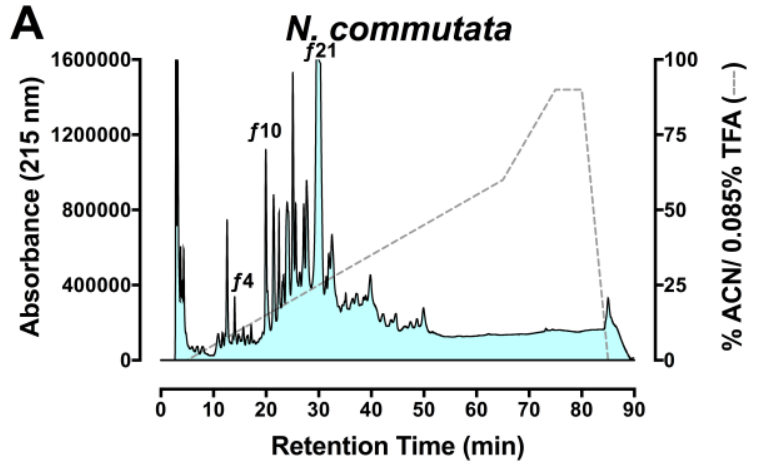

B

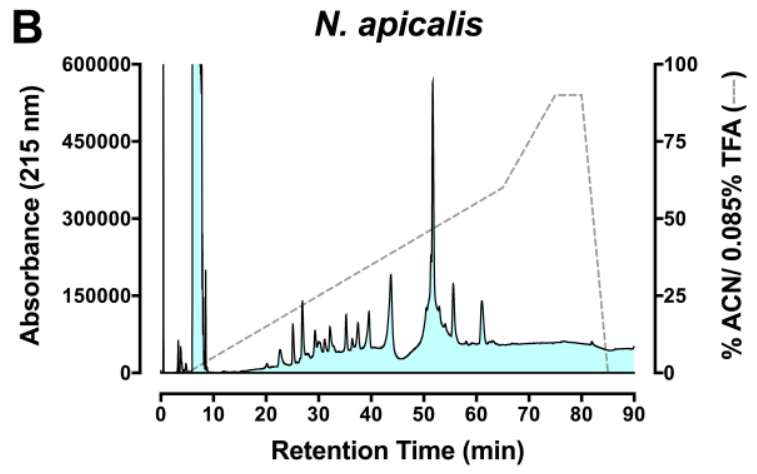

C

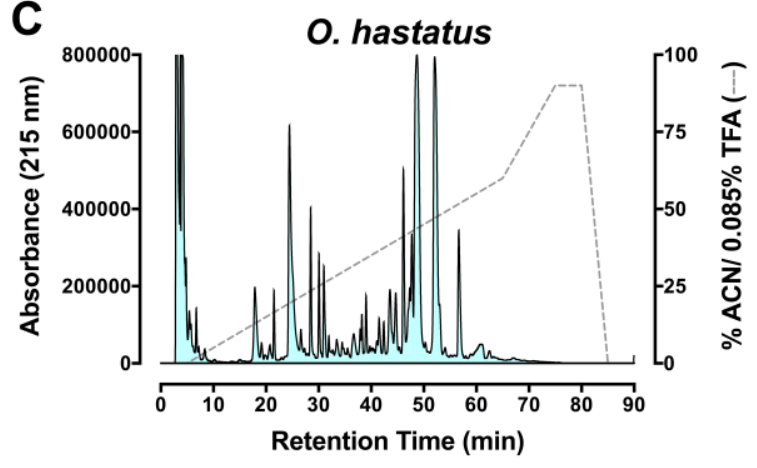

\section{Formicoids}
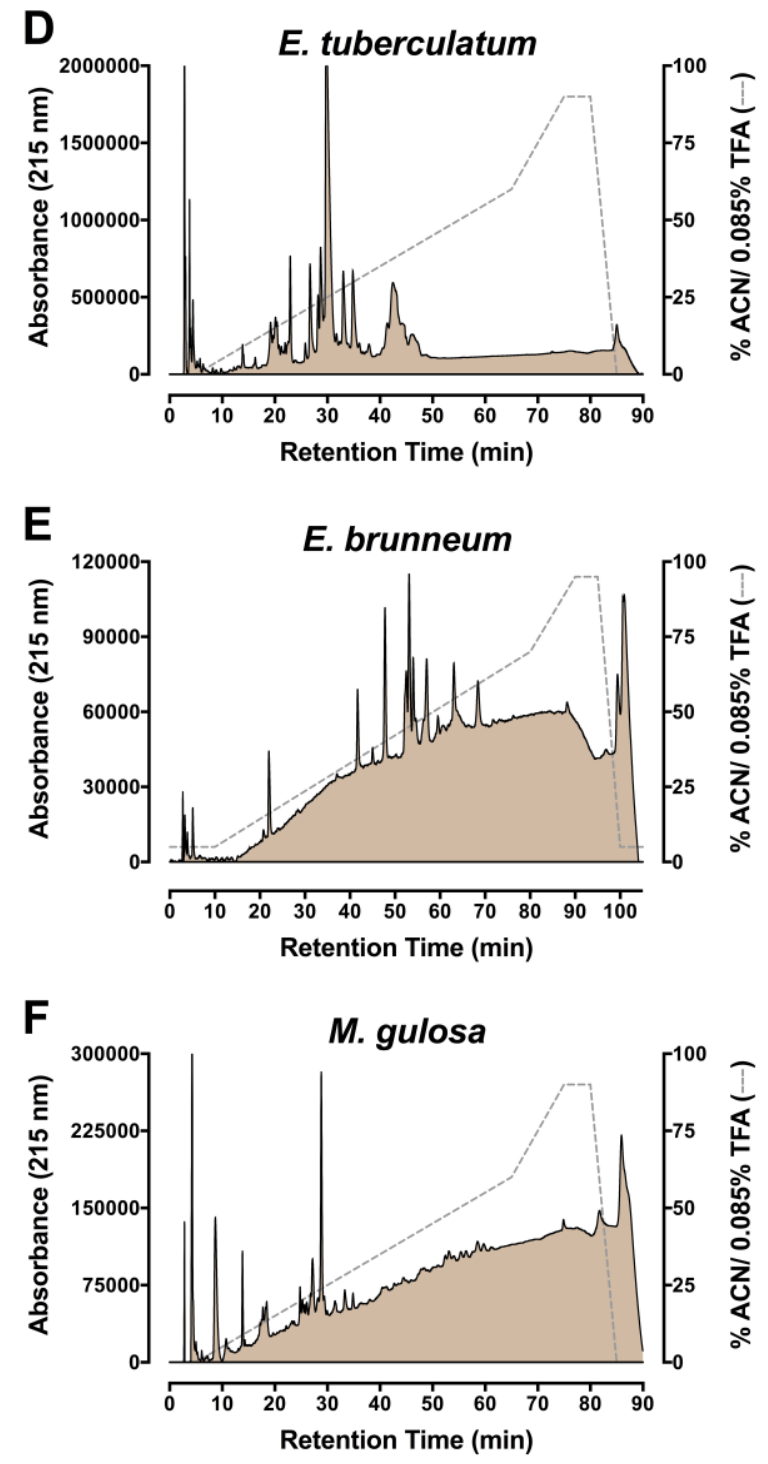


\section{Figure 3}
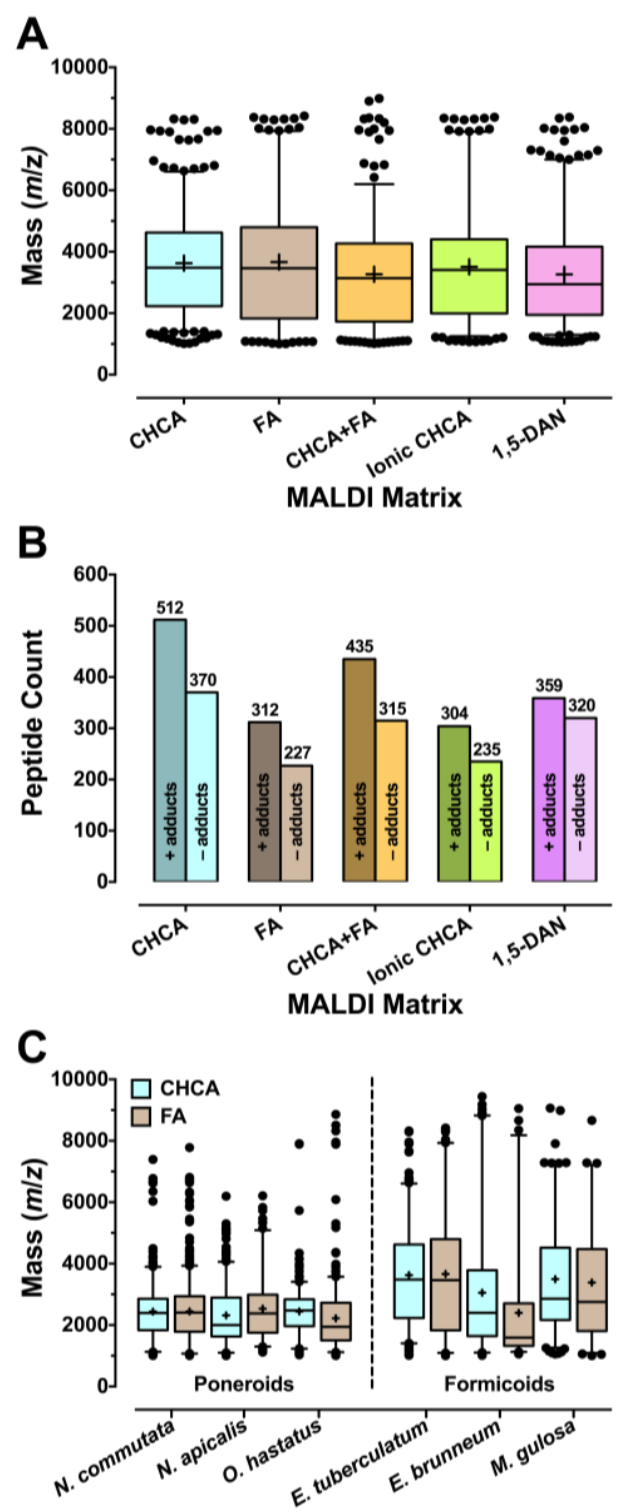
Figure 4

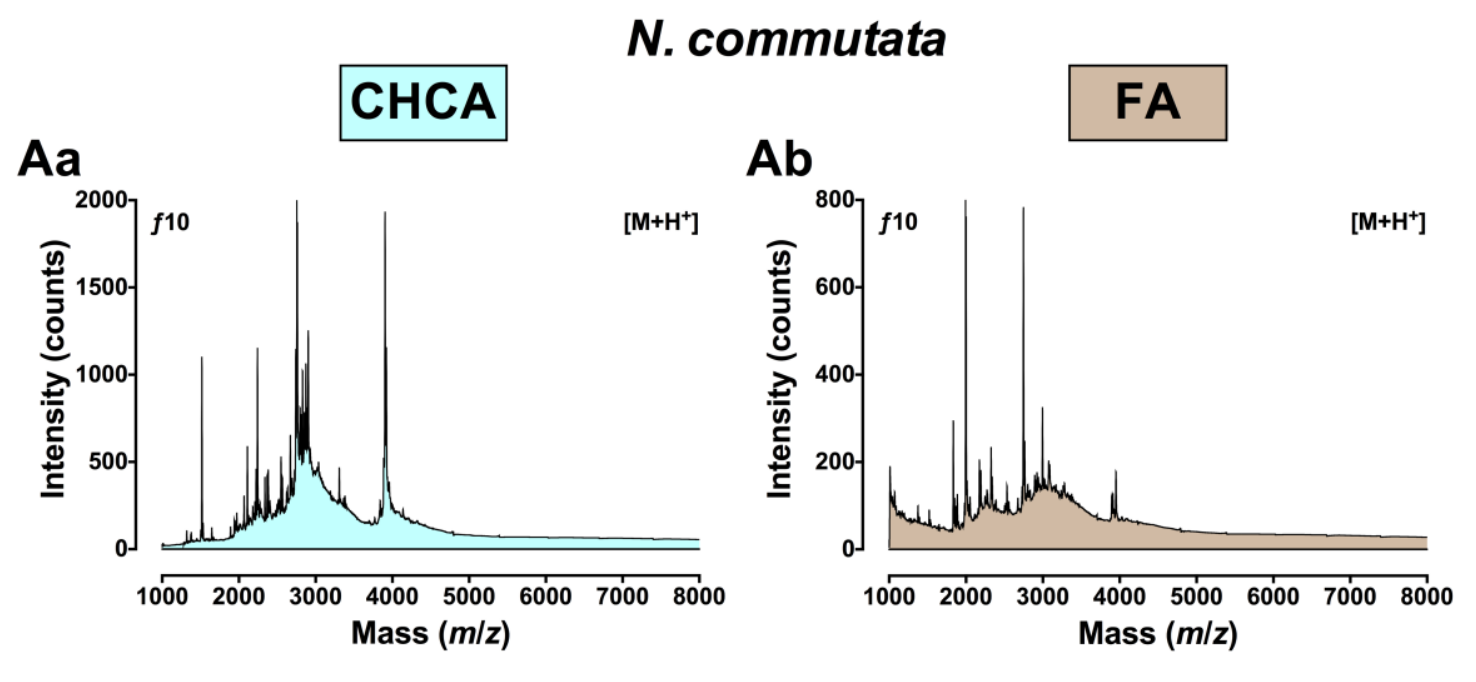

Ba

$\mathrm{Bb}$
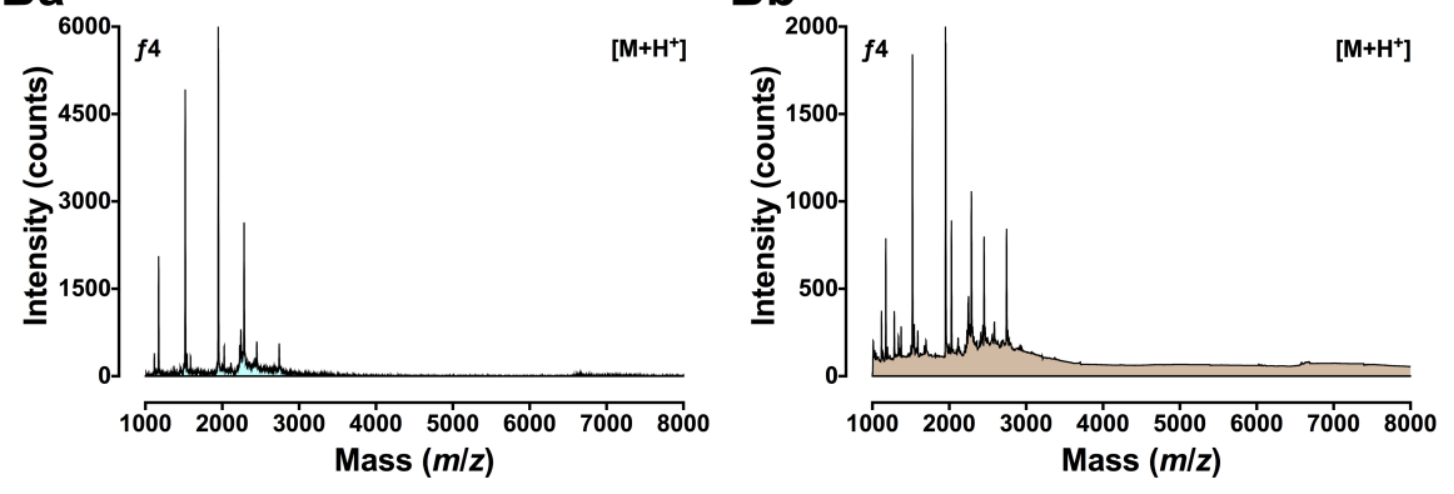

Ca

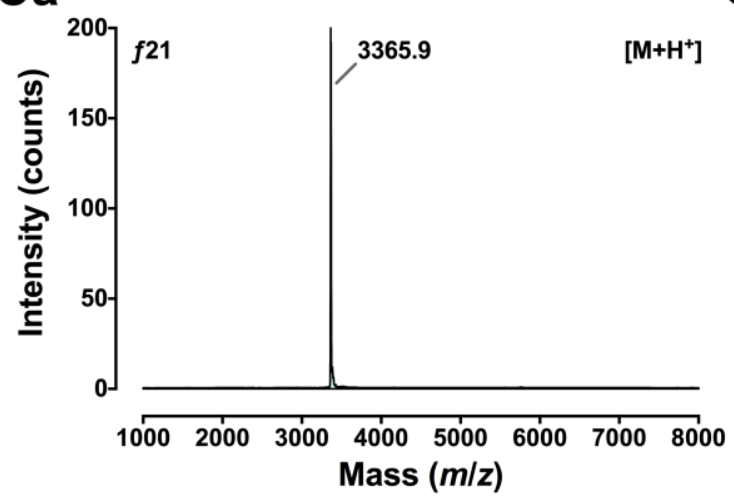

$\mathrm{Cb}$

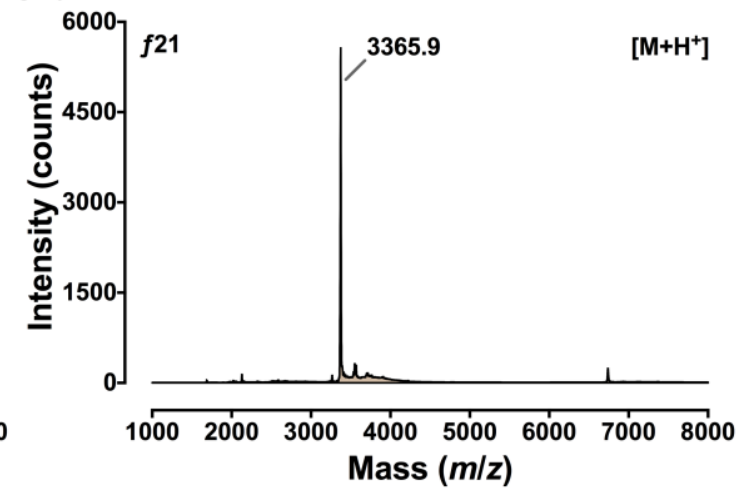




\section{Figure 5}

\section{Poneroids}

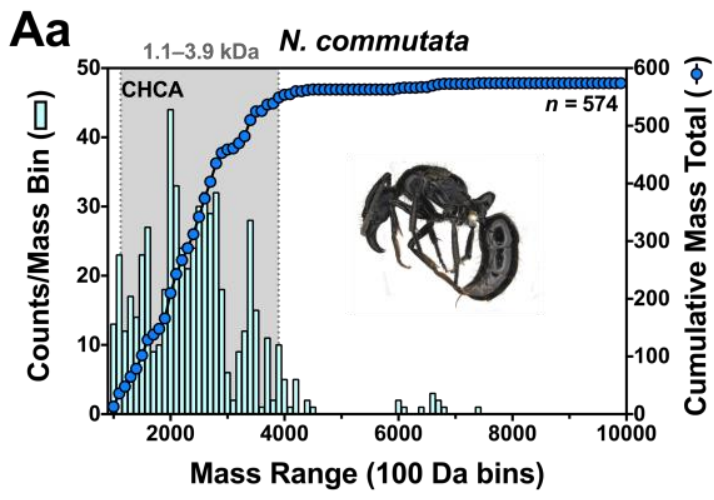

$A b$
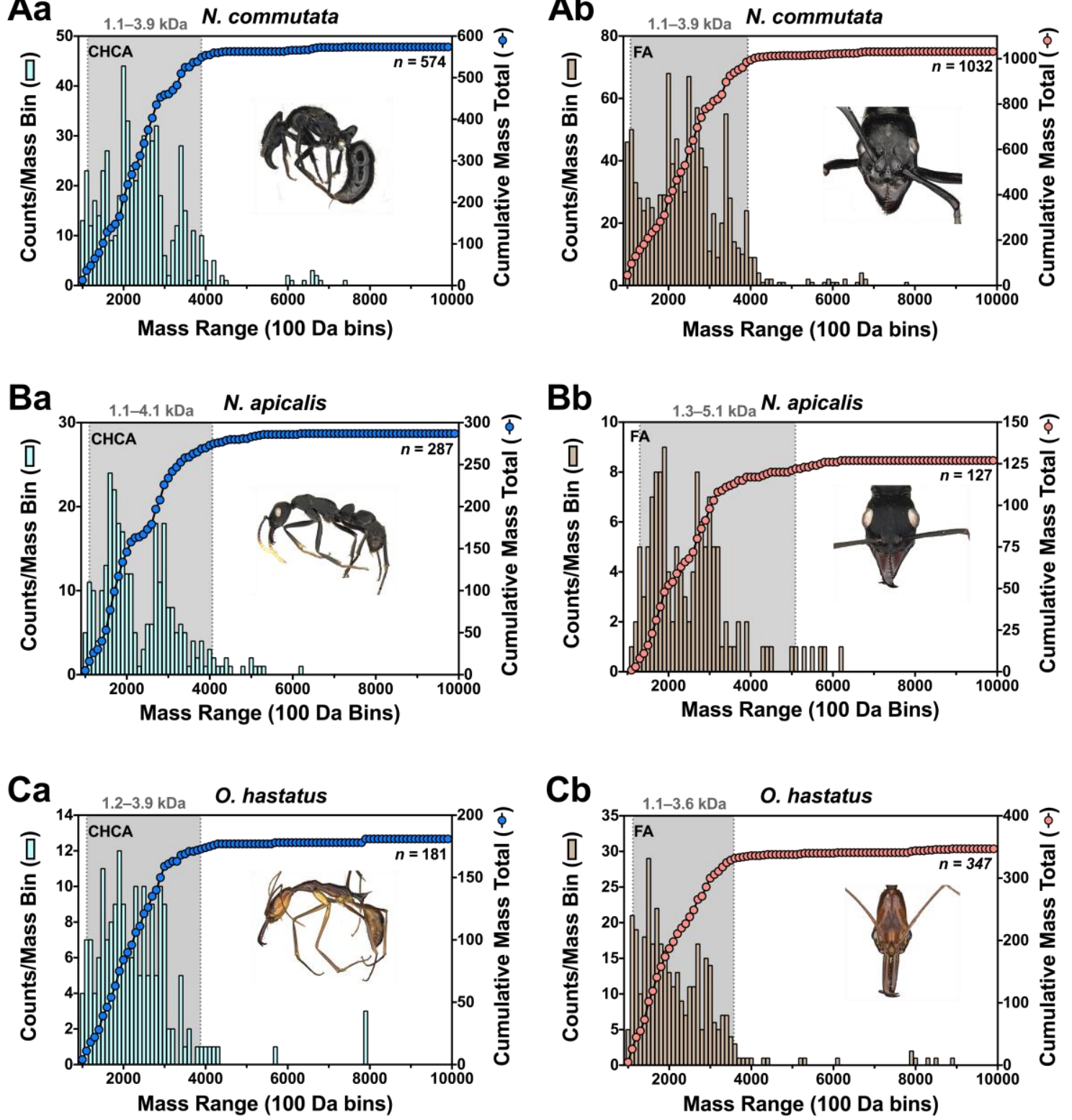
Figure 6

\section{Formicoids}

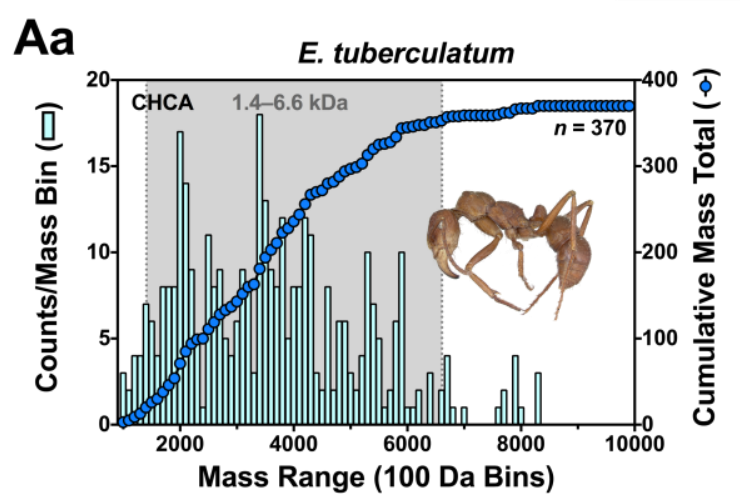

Ab
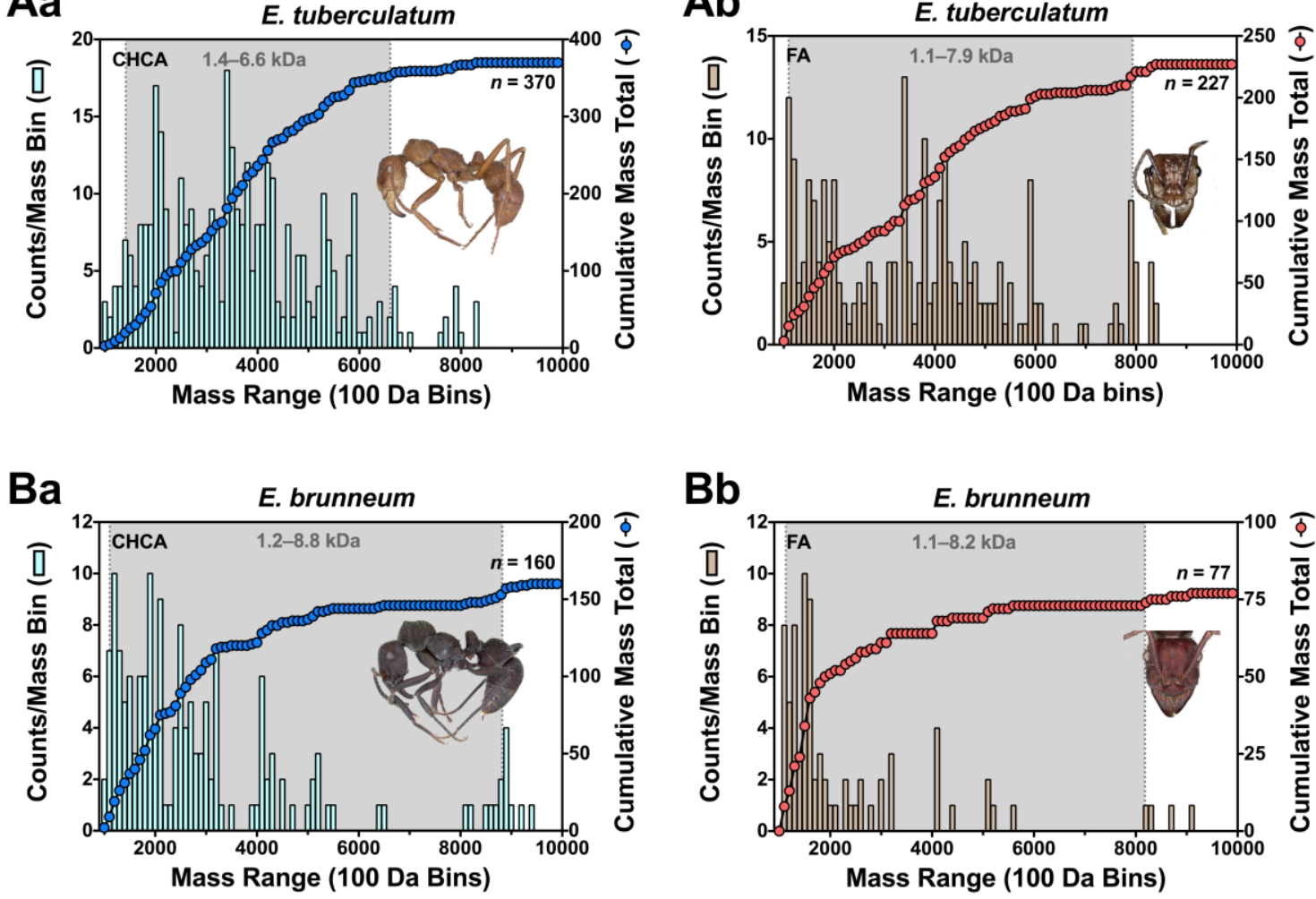

$\mathrm{Bb}$
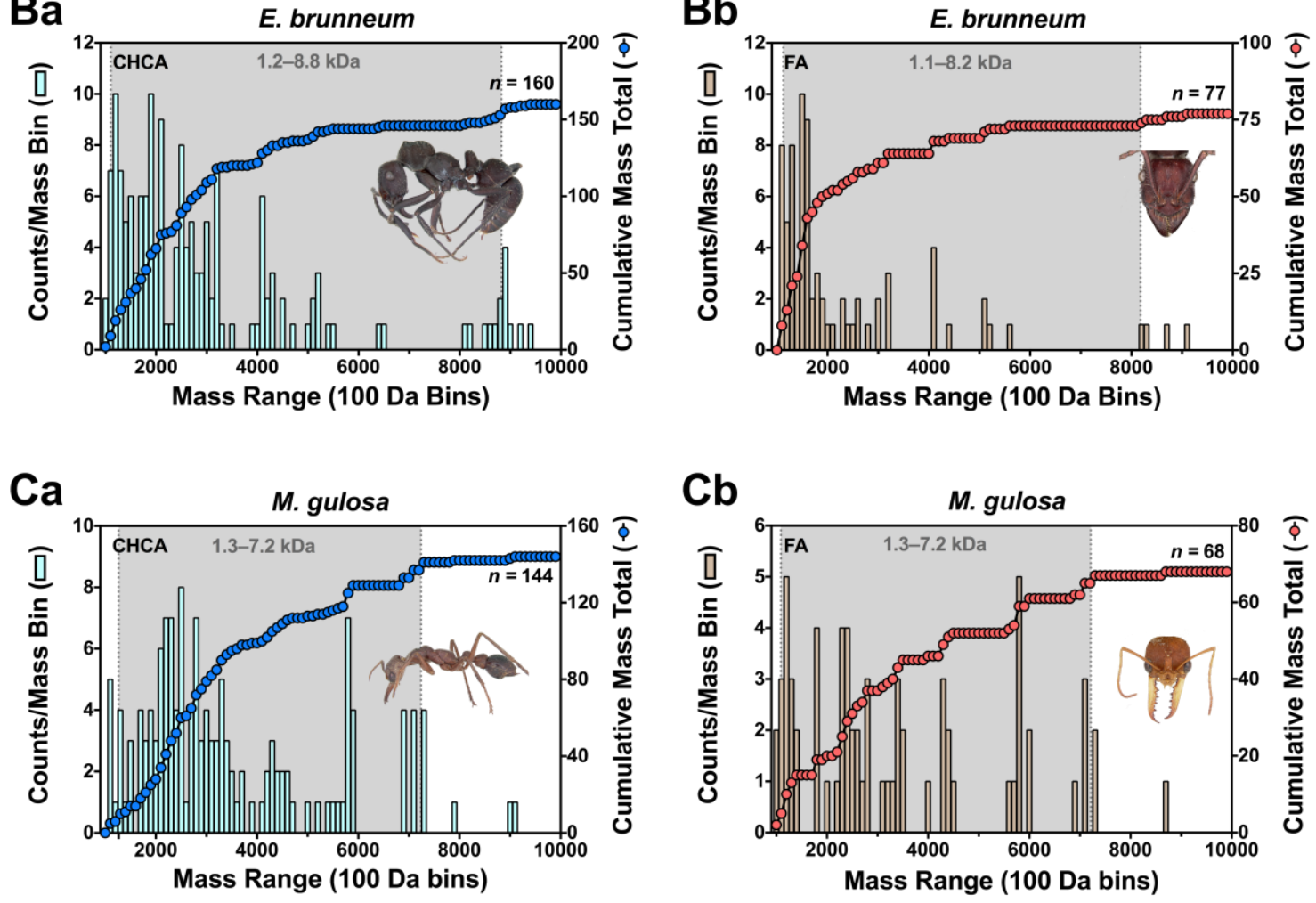
Figure 7

\section{Poneroids}

N. commutata

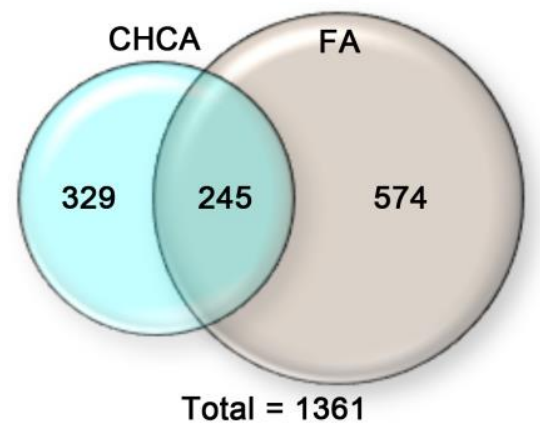

N. apicalis

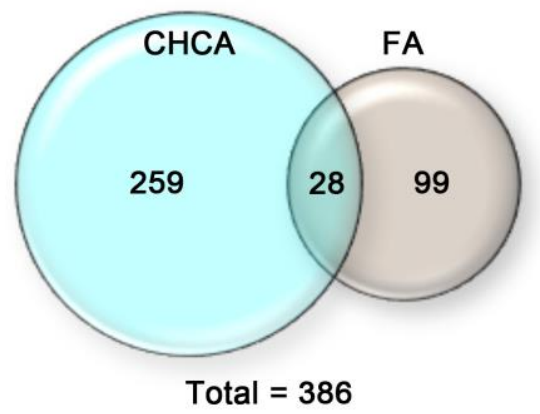

O. hastatus

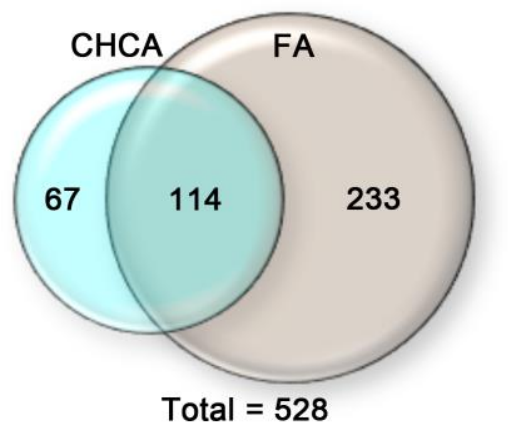

Formicoids

E. tuberculatum

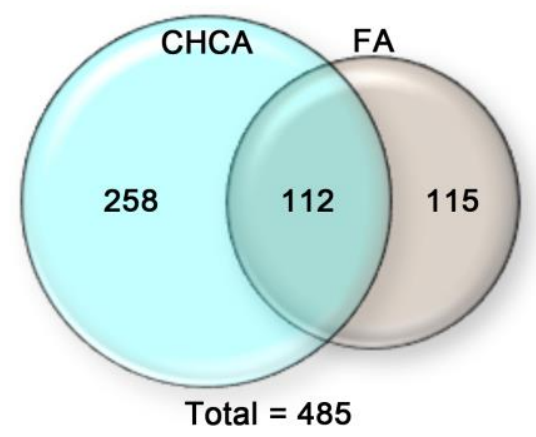

E. brunneum

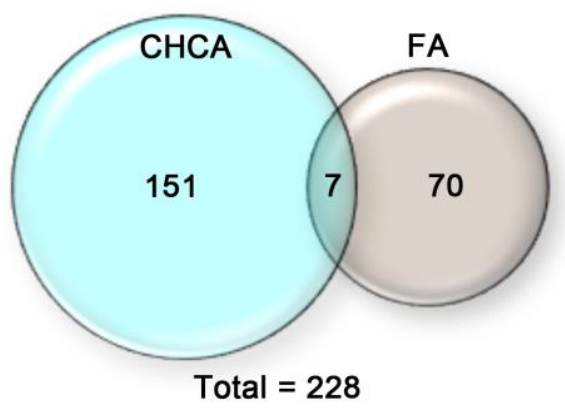

M. gulosa

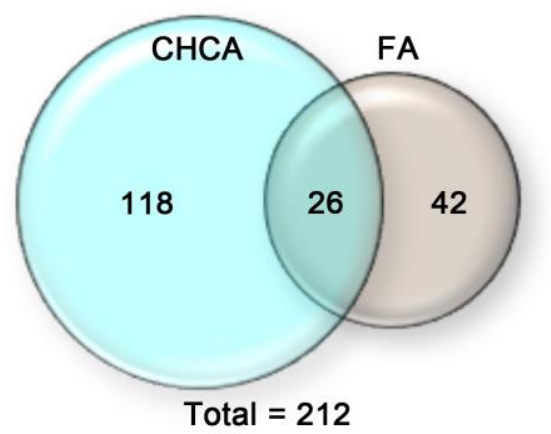




\section{Figure 8}
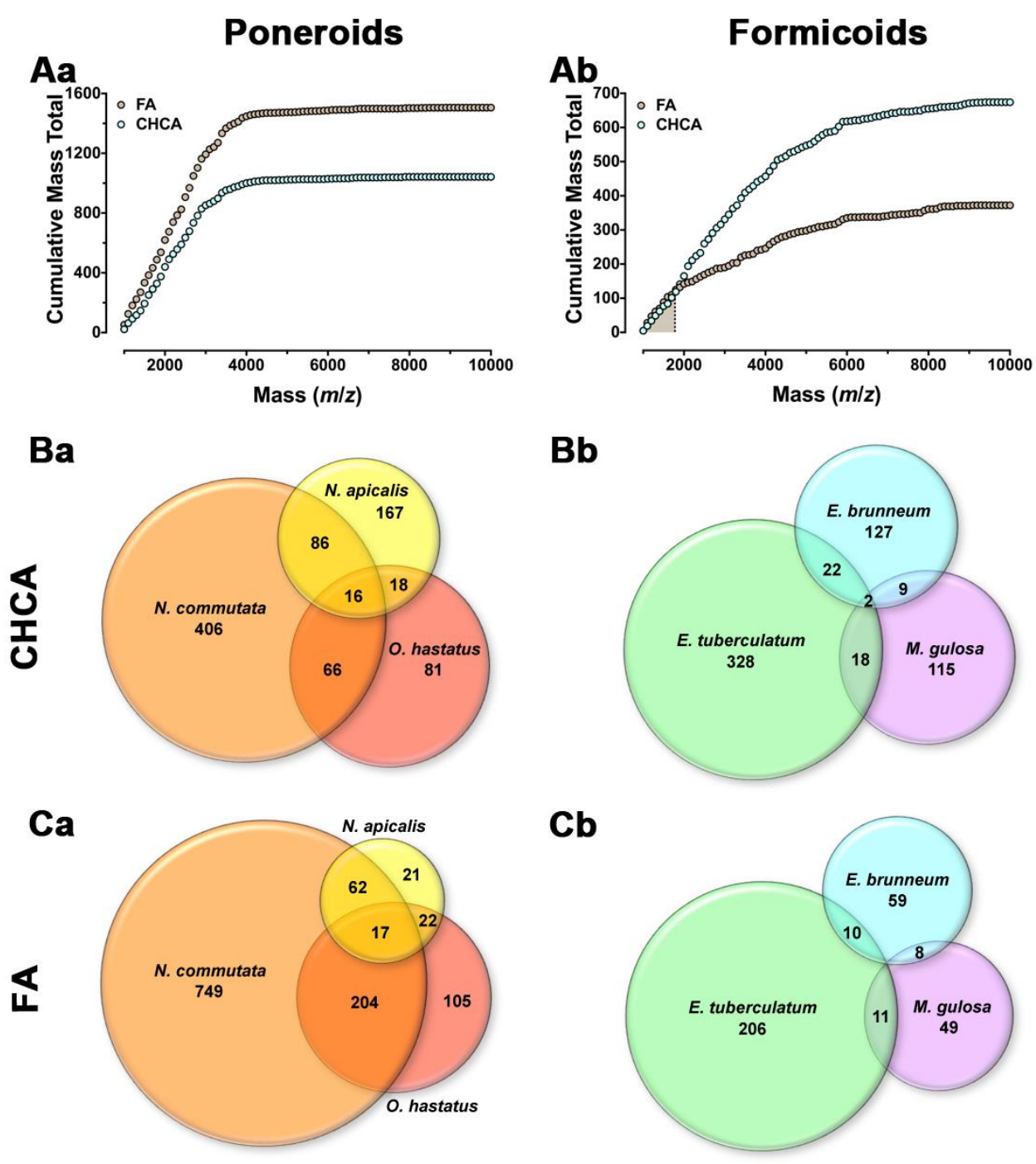

Cb

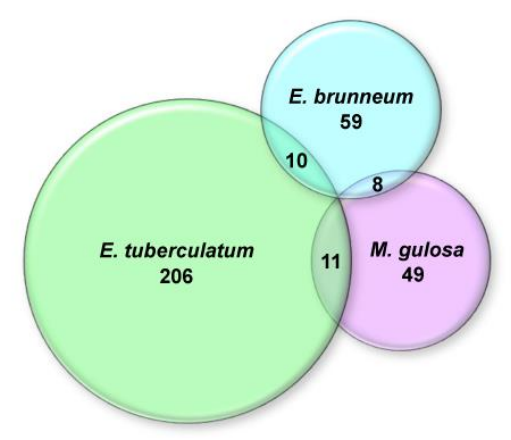




\section{Figure 9}

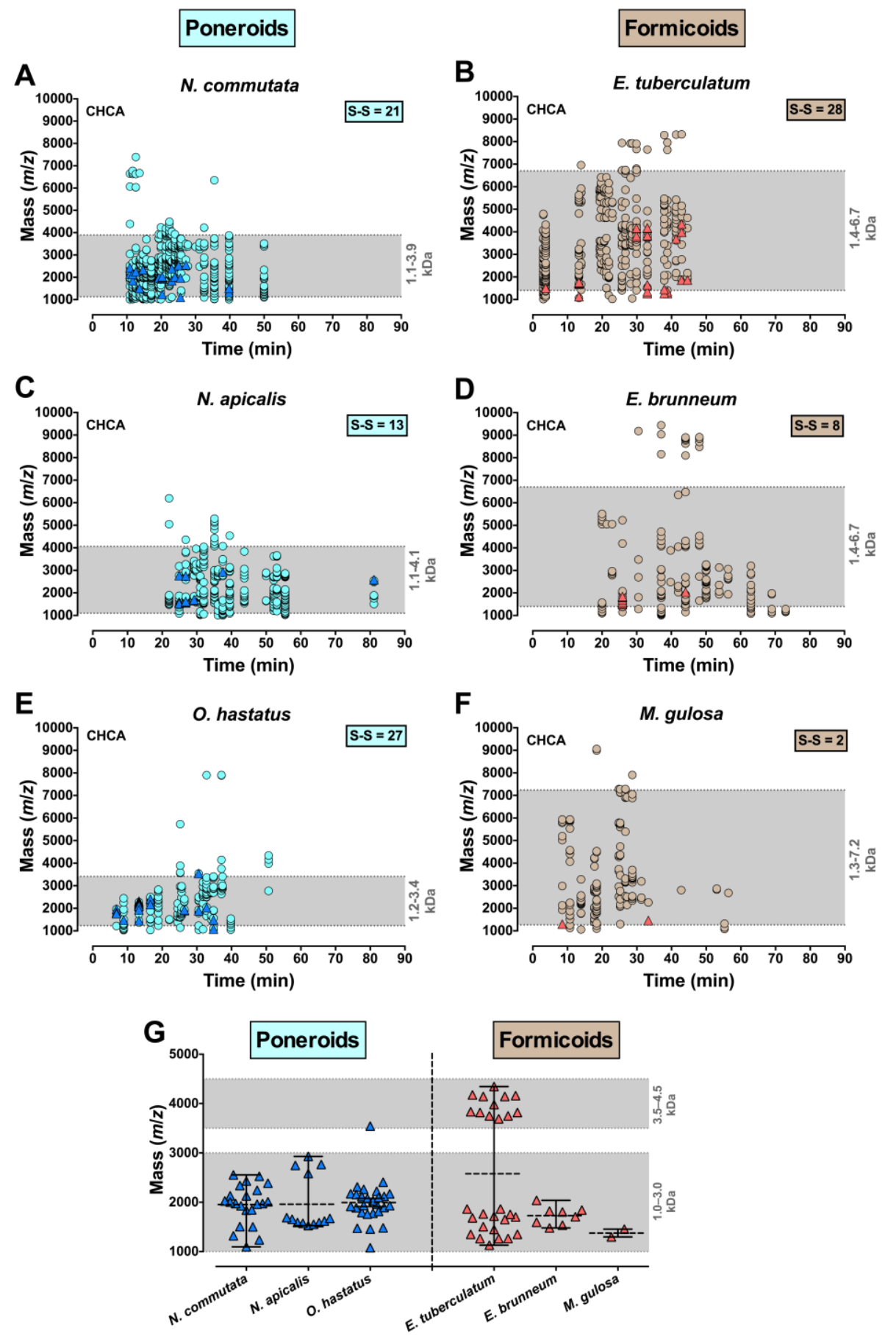

